\title{
A Preliminary Analysis of Patent Trends for Magnetic Fusion Technology
}

\author{
L. O. Levine \\ W. B. Ashton \\ R. S. Campbell
}

February 1984

Prepared for

Oak Ridge National Laboratory

under a Related Services Agreement

with the U.S. Department of Energy

Contract DE-AC06-76RLO 1830

Pacific Northwest Laboratory

Operated for the U.S. Department of Energy

by Battelle Memorial Institute 


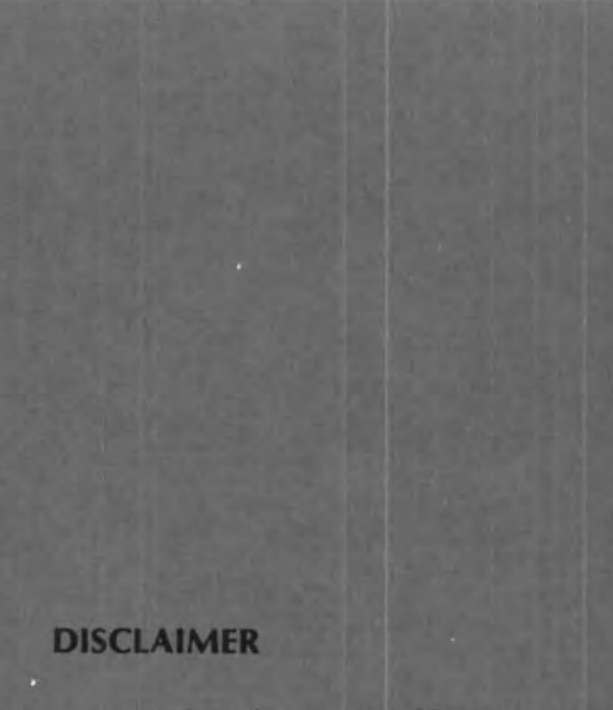

This report was prepared as an account of work sponsored by an agency of the United States Government. Neither the United States Government nor any agency thereof, nor any of their employees, makes any warranty, express or implied, or assumes any legal liability or responsibility for the accuracy, completeness, or usefulness of any information, apparatus, product, or process disclosed, or represents that its use would not infringe privately owned rights. Reference herein to any specific commercial product, process, or service by trade name, trademark, manufacturer, or otherwise, does not necessarily constitute or imply its endorsement, recommendation, or favoring by the United States Government or any agency thereof. The views and opinions of authors expressed herein do not necessarily state or reflect those of the United States Government or any agency thereof.

\author{
PACIFIC NORTHWEST LABORATORY \\ operated by \\ BATTELLE \\ for the \\ UNITED STATES DEPARTMENT OF ENERGY \\ under Contract DE-AC06-76RLO 1830
}

Printed in the United States of America Available from

National Technical Information Service United States Department of Commerce 5285 Port Royal Road Springfield, Virginia 22161

NTIS Price Codes Microfiche A01

Printed Copy Pages

Price

001-025

026-050

051-075

076-100

101-125

$126-150$

$151-175$

$176-200$

201-225

226-250

251-275

276-300

Codes 
A PREL IMINARY ANALYSIS OF PATENT TRENDS FOR

MAGNETIC FUSION TECHNOLOGY
L. 0. Levine
W. B. Ashton
R. C. Campbel1

February 1984

\begin{abstract}
Prepared for Oak Ridge National Laboratory under Related Services Agreement with the U.S. Department of Energy Contract DE-AC06-76RLO 1830
\end{abstract}

Pacific Northwest Laboratory Richland, Washington 99352 
. 


\section{EXECUTIVE SUMMARY}

This study presents a preliminary analysis of development trends in magnetic fusion technology based on data from U.S. patents. The research is limited to identification and description of general patent activity and ownership characteristics for 373 patents. The results suggest that more detailed studies of fusion patents could provide useful R\&D planning information.

\section{BACKGROUND}

Although magnetic fusion is a young technology, decades away from commercial applications, patent research of its component technologies is a useful program planning activity. Past experience indicates that basic research developments for many nascent technologies are patented at a very early stage of research. Moreover, these patents can provide useful R\&D planning information on issues such as patterns of component development or identification of spinoff research activity.

Pacific Northwest Laboratory (PNL) has developed a family of statistical and computer graphics techniques to describe technology development trends using patent indicators. The objective of this research is to provide a preliminary analysis of the nature of magnetic fusion patent activity and ownership characteristics using these PNL methods. Only a limited number of the PNL patent activity indicators are used in this research. Thus, an important focus of the work is to provide recommendations as to the value of further analysis using the more advanced PNL patent citation indicators.

\section{RESEARCH APPROACH AND FINDINGS}

After definition of the problem domain and the associated research objectives, a systematic patent search was undertaken. This search was based on a classification of fusion technology components to permit comparisons of research progress. Computer analysis of the resulting patent data was then completed and the graphical results were interpreted in light of the research objectives. 
The key findings from the patent indicator output are:

o No dramatic change in the aggregate level of 10-15 magnetic fusion patents per year has occurred since 1965 .

- Patents assigned to the U.S. government constitute a majority of the the patents studied. However, a surprisingly high percentage (12\%) of the patents are held by independent inventors.

- U.S.-held patents comprise $80.7 \%$ of all patents with the balance owned by foreign assignees. France $(6.4 \%)$ and West Germany $(3.8 \%)$ are second and third in activity, respectively. No foreign patent activity shows any recent burst of activity; however, most of the Japanese patent activity (2.1\%) has occurred since 1977 .

- Three technical areas -- heating, ion/plasma generation, and magnetic field geometry -- dominate the 14 categories analyzed with $67.3 \%$ of all patents. Of these areas, ion/plasma generation patent activity has decreased slightly in recent years while the other areas have remained stable.

o Most U.S. government, foreign, and U.S. private patents occur in the same three technical areas identified above. However, corporate assignees have a greater patent emphasis than others in tritium breeding, process utilization, and electric power equipment.

\section{RECOMMENDATIONS FOR FURTHER RESEARCH}

Given these results, the study recommendations for further work emphasize selective analyses to aid in fusion program planning, justification and evaluation. Several types of follow-on patent analysis studies are possible, but research into technical progress should be limited to the three major technical areas identified. Patent citation analysis could be useful in these studies for more in-depth research of linkages between technical areas, inventors, and assignees. For all technical areas, highly cited patents could be identified as a partial measure of the technical significance of research work. In broader program evaluation studies, patent references outside the study set 
could be reviewed to characterize "spinoff developments" from fusion research. Analysis of the research productivity by various organizations could also be conducted with patent data to identify the payoffs from publicly-funded work.

This study also suggests that, since R\&D program planning and evaluation involve multidimensional measures of performance, patent data could be combined with bibliometric analysis of scientific literature to add addditional observations on research outcomes. Technical leaders, cross-fertilization of developments, and areas of high or low progress could be identified in these studies to support program evaluation requirements. 



\section{ACKNOWLEDGEMENTS}

The authors of this document would like to acknowledge the important contributions of several members of the Pacific Northwest Laboratory research staff. Mr. Wade E. Bickford and Dr. David A. Dingee provided technical consultation for the fusion technology classification and interpretation of the results. Mr. Carl H. Imhoff provided assistance with the computer analysis.

Finally, this study would not have been completed without the assistance of Dr. Thomas J. Kuehn, Executive Director, Energy Research Advisory Board, U.S. Department of Energy. We appreciate $h$ is support. 


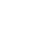




\section{TABLE OF CONTENTS}

EXECUTIVE SUMMARY ..................... . $\ldots$...

ACKNOWLEDGEMENTS ............................. vi

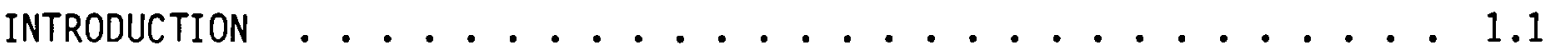

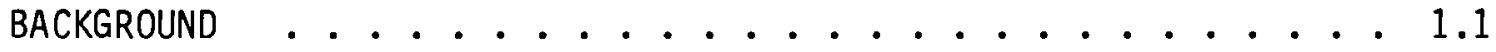

RESEARCH OBJECTIVES AND SCOPE ............. 1.2

THE VALUE OF PATENT ANALYSIS FOR NASCENT TECHNOLOGIES $\ldots \ldots .$.

OUTLINE OF THE STUDY ................. 1.5

STUDY METHODOLOGY . . . . . . . . . . . . . . 2.1

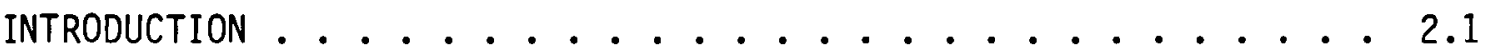

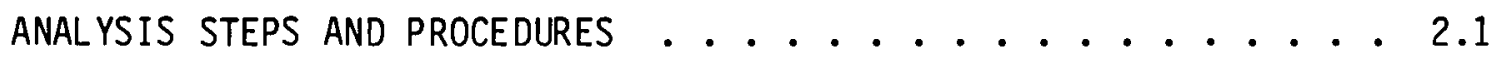

FUSION PATENT DATA BASE AND TECHNOLOGY CLASSIFICATION . . . . . 3.1

FUSION PATENT TECHNOLOGY CLASSIFICATION .......... . . . 3.1

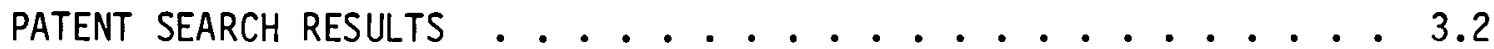

ANALYSIS AND FINDINGS . . . . . . . . . . . . . . . 4.1

AGGREGATE ACTIVITY AND OWNERSHIP TRENDS .......... 4.1

Activity Disaggregated by Assignee Sector ........ 4.1

Corporate Assignees . . . . . . . . . . . 4.3 4.3

Activity Disaggregated by Country .......... 4.5

FUSION TECHNOLOGY TYPE COMPARISON ............. 4.8

Technology Type Activity Trend Results . . . . . . . 4.8

Techno logy Type Activity by Country and Sector . . . . . . 4.8

A SUMMARY OF RESEARCH FINDINGS ............. 4.14

RECOMMENDATIONS FOR FURTHER RESEARCH . . . . . . . . 5.1

EXPANDED PATENT ANALYSIS ................ 5.2

BIBLIOMETRIC STUDIES ................. 5.3

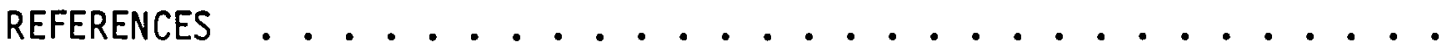

APPENDIX A: MAGNETIC FUSION TECHNOLOGY TYPE CATEGORIES . . . . . A.1

APPENDIX B: A LISTING OF MAGNETIC FUSION PATENTS ......... B. . . 1 


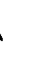

. 


\section{LIST OF FIGURES}

Figure 1. Battelle Patent Analysis Process . . . . . . . 2.2

Figure 2. Magnetic Fusions Aggregate Patent Activity . . . . . 4.2

Figure 3. Patent Activity by Sector . . . . . . . . . . . 4.4

Figure 4. Patent Activity by Country . . . . . . . . . 4.7

Figure 5. Patent Activity by Technology Type . . . . . . . . 4.10

Figure 6. Patent Activity by Technology Type . . . . . . . . 4.11

\section{LIST OF TABLES}

Table 1. Battelle Patent Analysis Process . . . . . . . . 2.2

Table 2. Class 376: Induced Nuclear Reactions, Systems and Elements . 3.4

Table 3. Breakdown by Sector . . . . . . . . . . . 4.3

Table 4. Patent Activity for the Top Six Assignees . . . . . . 4.5

Table 5. Breakdown by Country . . . . . . . . . 4.6

Table 6. Breakdown by Technology Type . . . . . . . . 4.9

Table 7. Technology Type/Country Cross Tabulation . . . . . . 4.12

Table 8. Technology Type/Sector Cross Tabulation ........4.13 


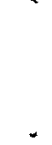


A PRELIMINARY ANALYSIS OF PATENT TRENDS

FOR MAGNETIC FUSION TECHNOLOGY

\section{$1.0 \quad$ INTRODUCTION}

This document presents a preliminary analysis of development trends in magnetic fusion technology based upon data from the U.S. patent system. The study scope is limited to identification and description of broad patterns of technology change from 373 patents. However, the results suggest that additional, more detailed studies of fusion patents could provide useful research planning information.

\subsection{BACKGROUND}

The current state of development in magnetic fusion technology suggests that commercial applications are decades away. Substantial engineering and system development problems must still be overcome (Conn, 1983). However, progress in fusion research is a matter of great current national interest because of the important need for reliable and low pollution energy sources. Thus, even for a very young technology like magnetic fusion, using all sources of planning information -- including patents -- is an important strategy for effective research and development (R\&D) program management.

There are a number of ways of detecting and documenting technological progress. Pacific Northwest Laboratory (PNL) has developed several well-known analytic tools for tracking and predicting technological change using data from patents (Campbell and Nieves, 1979). These tools, called the Battelle Patent Indicators, have proven valuable for a variety of research and development planning studies in previous applications. The PNL methods are able to evaluate several key parameters of progress and change in areas of technical R\&D which result in patents. For example, questions such as the following have been addressed in previous patent analysis studies:

- Are technological developments occurring primarily in narrow areas of a field or is progress occurring in several areas? 
o Are shifts occurring in the focus or pace of technological development?

o Are the developments being carried out by many organizations or by on Ty a few?

- Have developments been primarily due to private initiative, or have they been heavily influenced by federal support?

o Is there a cohesive body of patents in the field, or are significant patents scattered among many different topics?

o What can be inferred about the level of foreign interest in the field from the number of foreign-held patents?

Patent data provide a unique and valuable source of information with which issues such as these can be investigated.

\subsection{RESEARCH OBJECTIVES AND SCOPE}

The purpose of this study is to provide a preliminary analysis of the nature of developments in magnetic fusion technology using U.S. patent data. The research will be limited to a description of the general characteristics of patent activity and assignees for major fusion technology components. The trends in some key activity variables over time are also examined where information on patent filing or issue dates provide useful insights.

This research is not intended as a comprehensive analysis of fusion patent data. The study is preliminary in nature; its focus is to evaluate recent magnetic fusion patent data and to develop recommendations concerning the advisability of more detailed research of patent information. More advanced methods to evaluate patent trends, such as analys is of patent citations or combining patent data with expert judgement, are not undertaken in this study. Also, information on cross-referencing to foreign patents or to other R\&D program indicators is not considered.

\subsection{THE VALUE OF PATENT ANALYSIS FOR NASCENT TECHNOLOGIES}

An important question can be raised concerning the significance of patent analysis when applied to a technology such as magnetic fusion which has a long 
development period and which is far from commercialization. However, on the basis of past experience, it appears that patent analysis does have utility in some of these cases as an aid for planning or evaluating development program activities. First, historical evidence indicates that for many youthful and basic technologies, significant patenting of new developments has occurred (Carpenter, 1980). Economic motivations are not the only reasons to patent. There are non-economic uses of patents -- from the standpoint of the inventory and the assignee (patent owner) -- to be considered earlier in the development cycle than is generally practiced. Furthermore, the technical content of these patents, taken together, may hold useful information for R\&D program or investment planning. Finally, patent data is valuable for evaluation of research program technical progress, even in nascent technical areas.

Within some parts of the scientific community there is little regard for patenting the kinds of basic inventions which emerge from fundamental research, rather than applied research. The historical association of patenting with the creation of a product monopoly no doubt contributes to this situation. The fact is that a substantial percentage of truly basic discoveries in the last fifty years have been patented. Fermi, for example, patented the nuclear pile -- clearly a basic invention (his family received $\$ 50,000$ ).

Many scientists use the patent system not for profit but to establish "priority" or order-of-discovery. Given the number of multiple, independent discoveries within the U.S. patent system, this is not a trivial issue. A U.S. patent in this situation provides a government certificate of originality and priority, qroduced by a disinterested third party. Further, by virtue of the special characteristics of patent referencing, the position of a patented discovery relative to the state of the art is often spelled out in detail (particularly if one reads the correspondence generated during the rejection/ amendment process).

A scientist's professional stature is strongly determined by receiving proper scientific credit for his or her inventions and discoveries. This can be problematic in turbulent, emerging areas where the research front may be changing rapidly. The professional stakes involved are obviously very high for individual or group that leaps some of the present technical hurdles in an area such as fusion. Thus, patents will be sought even by those with no profit motive. 
Beyond establishing scientific credit for professional reasons, from the standpoint of governments and firms there is often a need or a reasonable rationale for defensive patenting to protect multi-billion dollar R\&D investments from opportunistic, nuisance, or offensive patents. The objective of such patenting is often not to exclude others, but for an assignee or inventor to protect themselves from being excluded from an area of interest by patent actions of others.

These characteristics of patenting behavior suggest two broad aspects of program management for youthful technologies that can benefit from patent studies. First, from the standpoint of program evaluation, patent data can provide important information either on the research productivity or the significance of research activity from participating individuals or groups. Second, as a program planning and justification too1, patent data allow insights into the performance of competitors -- in particular to monitor foreign competition. In addition, patents permit identification of indirect research benefits such as "spinoff developments" in related technical areas. Patents are of course also an extensive and wel1-documented source of innovative ideas.

For these reasons, the patent system can be productively used to monitor and evaluate technical developments in areas that are far from commercialization. While not the only source of technical information, patents can provide valuable insights into the current state of the art of an emerging technology.

(1) We have defined defensive patents as those patents assigned to an organization or individual covering a parallel invention or variant. These could be potential competitive inventions to those which are generally not intended to be "worked," i.e., produced; but used to limit a competitor's more basic patents or to establish a negotiating position for cross-licensing agreements. Thus, offensive patents as defined here are not generally alternatives to the basic patent, but improvements or applications (i.e., minor spinoff inventions). 


\subsection{OUTLINE OF THE STUDY}

Section 2 of this study presents the general approach to performing a patent trend analysis and describes the specific steps used in this preliminary study of magnetic fusion. The details of the approach to fusion technology classification and the patent search are given in Section 3. Analysis results are then presented in Section 4 , where both the aggregate trend data and the findings from the technology classification comparison are given. Section 5 contains recommendations for further work. 


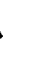

. 


\subsection{STUDY METHODOLOGY}

The general research approach for this study is summarized in this section. The methods presented here are based on more detailed discussions of patent analysis in previous Battelle research studies (Campbell and Nieves, 1979).

\subsection{INTRODUCTION}

The major objectives of this research are to better understand the nature of technological patent activity and the composition of patent ownership for magnetic fusion technologies. The analysis undertaken to accomplish this task used information from U.S. patents of both U.S. and foreign origin. Abstracted data from these patents was analyzed by statistical techniques to identify trends or patterns in the technology.

\subsection{ANALYSIS STEPS AND PROCEDURES}

A sumary of the analysis process is contained in Figure 1. Each of the major steps is summarized below along with comments regarding the analysis procedures used to complete the research task.

Step 1 concerns formulation of the research problem. In general, this process includes identification of the technology area to be studied as well as definition of the particular problem domain of the technology area which is the specific focus of the work. A problem domain is considered to be some aspect of a system or product's functional performance which is addressed by technological developments or solutions. One or more technical approaches to a set of related product or system development requirements may be the focus of patent activity in a problem domain. As an illustration, fuel injection, stratified charge formation, and electronic ignition are all technical approaches related to the problem domain of automotive fuel economy. 


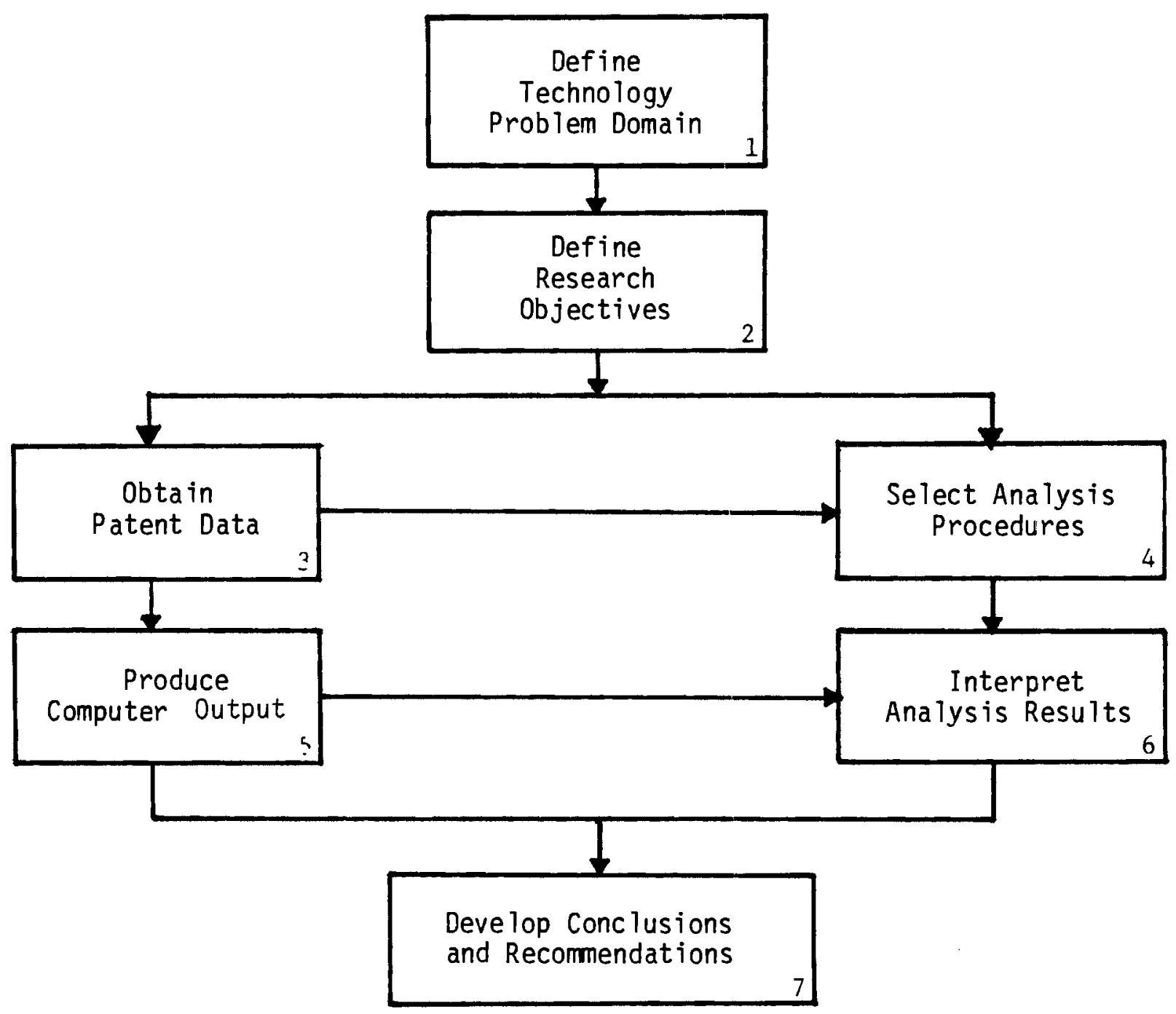

Figure 1. Battelle Patent Analysis Process 
Definition of the problem domain is an important step for identifying the set of patents relevant to a study and for interpreting their characteristics. The choice of an appropriate problem domain should be guided by both the area of technical interest and the specific questions and issues the analys is is designed to address. For this study the problem domain was defined to be general regarding technical area (magnetic fusion technology) and unfocused as to functional performance or problem (a11 aspects are relevant). Thus, al1 patents which are directly related to magnetic fusion research are of interest in this problem domain.

This step also includes a categorization of the technology in question into technical areas, subgroups, or components relevant to the overall problem domain. The resulting classification helps in identifying relevant patents and allows comparative analyses of the relative development activity, technical linkages, and assignees for the corresponding patent subgroups. The classification of magnetic fusion developed for this research is described in Section 3 .

Step 2 concerns formulation of the research questions to be addressed by the analysis. For this study the following concerns define the scope of the research:

o What are the significant areas and timing for technological developments and is progress apparent primarily in narrow areas of the magnetic fusion field?

o Is there a cohesive body of patents in the field, or are significant patents scattered among many different topics and many different organizations?

o Have developments been due to private initiative, or have they been heavily influenced by federal support?

o What can be inferred about the level of foreign interest in the field from the number of foreign-held patents?

These questions are addressed with the purpose of formulating recommendations on the value of more detailed follow-on, patent-based studies of fusion 
research. This study will only address patent activity and ownership. Advanced techniques, such as patent citation analysis, will not be covered in this research.

The patent search activity is covered in Step 3. The purpose of this step is to identify patents relevant to the analysis and to construct the patent study data set. The patent search may be conducted with two basic approaches -- first, using the U.S. Patent Office numerical classification system, and second, using selected patent title or abstract keywords. Often both methods are used, as was the case for this study.

Information on each analyzed patent was then entered into a computerized data base management system for subsequent analysis. For this preliminary patent evaluation, the information included:
- Patent Number
- Assignee Sector
- Issue Date (DDMMYY)
- Assignee Country
o Filing Date (DDMMYY)
- Technology Type
- Title (up to 68 characters)
- Inventor Name (up to 5 names)
o Assignee Name

After the data base is established, the specific analysis procedures and patent indicators are selected and organized in Step 4. For this study the Battelle Activity Indicators were the principle analysis tools used (Campbell, 1983). Computer analysis of the patent data set, including computer graphics, is conducted in Step 5 .

The tabular and graphic output from the computer processing are interpreted in Step 6. In some cases, other data sources are used to facilitate this process. For example, in this research PNL technical staff members familiar with fusion research provided expert knowledge to aid in understanding the patent analysis results.

Finally, the research process, analysis results, and study recommendations are documented in Step 7. 


\subsection{FUSION PATENT DATA BASE AND TECHNOLOGY CLASSIFICATION}

This section describes the technology breakdown used to classify the fusion patents into technological groups for further analysis and presents the results of the patent search process.

\subsection{FUSION PATENT TECHNOLOGY CLASSIFICATION}

In order to aid the patent search process and to permit a comparative analysis of fusion technology components, fourteen different magnetic fusion technical categories were established. A detailed explanation of these technology types, as well as other fields of the patent data base is included in Appendix $A$.

The technology categories are summarized below:

1. Magnetic Field Geometry and Confinement Schemes

2. Ion, Plasma Generation

3. Plasma Control/Field Shaping

4. Plasma Boundary/Impurity Control

5. Heating

6. Coil/Magnet Technology

7. Instrumentation/Diagnostics

8. Vacuum Technology

9. Tritium Breeding/Extraction/Recovery/Processing

10. Process Utilization of Fusion/Plasma Energy

11. Heat Generation/Blanket and Shield Designs

12. Power Conversion, Thermodynamic Cycles

13. Electrical Power Supplies/Power Storage/Switching/Transmission

14. Materials

These categories are similar to those used in DOE's computerized Energy Data Base (U.S. Department of Energy, 1983). The categories were developed in consultation with PNL staff experienced in magnetic fusion technology. During the patent search process, the patent office classification structure and the patents themselves served as additional inputs to define the scope of each category. 


\subsection{PATENT SEARCH RESULTS}

One of the most important elements of any patent trend analysis is the selection of the relevant patents. PNL conducted an extensive patent search for magnetic fusion-related patents. The patent set was initially limited to those patents issued after 1965. Three data bases were used in this search:

- Pergamon

- Claims/U.S. Patent Abstracts

o U.S. Patent Office (OTAF)

Table 1 contains the results of the Pergamon search for patents related to magnetic fusion using the keywords shown. Patents filed from January 1971 through March 1983 were included. An asterisk indicates a search for patents with any version of that keyword.

These patents were reviewed for class and subclass based on the patent Manual of Classification (U.S. Patent Office, 1981). Patents classified in areas thought to be irrelevant to the study scope were eliminated. The remaining patents were sorted by patent number. Patents duplicating those found in the Claims/U.S. Patent Abstracts data-base search were eliminated. This left a unique set of 260 potentially relevant patents not classified under Class 376 , the nuclear patent class (this patent class was revised in October 1981).

The Claims/U.S. Patent Abstracts search was limited to the years 19651982. It was restricted to patents referenced or cross-referenced to Class 376, Subclass 121-150; 331 patents were found. Table 2 lists these subclasses.

The U.S. Patent Office search of the same subclasses yielded 451 for the period 1963-1982. Limiting the years to 1965-1982 reduced the total to 329. A comparison of the patent numbers listed against the Pergamon and Claims/U.S. 
TABLE 1. Keyword Search Results

Keyword

Number

of Patents

Magnetic (or thermonuclear or nuclear) and Fusion

95

Plasma and Fusion

30

Tritium and Fusion

8

Magnet* and Plasma

223

Tokomak

12

Fusion and Reactor Wall

2

Neutral and Beam*

101

Plasma and Confine*

29

Toroid* and Magnet

$\underline{171}$

TOTAL

671 
TABLE 2. Class 376: Induced Nuclear Reactions, Systems and Elements (From Manual of Classification Order 811 - October 15, 1981)

100 NUCLEAR FUSION

121 . Magnetic confinement of plasma

122 ...Plasma formed in situ by laser

123 ..Principal heating by wave energy

124 ... Heating by time varying magnetic field (e.g., by compression)

125 ... Imploding liners

126. With enveloping charged particle confinement (e.g., E or P layer)

127 ..With injection of electrically charged or accelerated particles

128 ...Plasma injection

129 ....Negatively charged particle injection

130 ....Neutral particle injection

131 ...Auxiliary heating

132 ....Electromagnetic wave energy

133 ..Toroidal confinement of plasma

134 ....Divertors

135 .....Effuser

136 ...Limiters or liners

137 ...With solid internal conductor

138 ....Bumpy torus

139 ...Linear confinement

140 ... Mirror devices

141 ....Plasma formed or contained between spaced electrodes

142 . .Magnetic structure

143 ...With circuitry

144 .Plasma formed between spaced electrodes

145 ...Plasma focus

146 . Including removal or use of impurities or reaction products (e.g., energy)

147 ..Direct conversion of energy

148 ... Including use of heat or radiation to effect a chemical reaction

149 . Shock wave heating of plasma or gas (e.g., MHD heating)

150 . Chamber structure or material 
Patent Abstracts searches showed five patents not previously found. This resulted in a list of 596 distinct patents:

\begin{tabular}{lc} 
Data Base & $\begin{array}{r}\text { Number of Magnetic } \\
\text { Fusion Patents }\end{array}$ \\
\cline { 2 - 2 } Pergamon & 260 \\
Claims/Abstracts & 331 \\
Patent Office & $\frac{5}{596}$
\end{tabular}

Copies of these 596 patents were then acquired and individually reviewed for their relevance to the magnetic fusion problem domain in this study. This resulted in a final list of 373 patents for inclusion in the data base. In short, the search identified 37 patents beyond those classified in Class 376 , Subclass 121-150.

A listing of the 373 patents (in patent number order) is included in Appendix B. 
. 


\subsection{ANALYSIS AND FINDINGS}

The magnetic fusion patent data base was individually sorted on specific fields to permit a more detailed analysis of both static characteristics as we 11 as trends in the data over time. Aggregate patent activity (total number of patents per year) was analyzed initially to identify general trends. Significant corporate assignees were identified. Yearly patent activity for assignee sector, country, and technology type were also reviewed. In addition, breakdowns of patent activity by technology type were analyzed separately.

\subsection{AGGREGATE ACTIVITY AND OWNERSHIP TRENDS}

The solid line in Figure 2 plots the total number of magnetic fusion patents issued from 1965 through 1982. The dashed line represents the filing date of these issued patents. This means that not all patents filed before 1965 are plotted; only those which were filed in 1965 and issued in 1965 or later are included. In addition, the sharp decline in filings in 1981 and 1982 is a result of the average 2-3 year time lag between the filing and issuance of a patent. Only patents issued before January 1, 1983 were included for analysis. These patents were filed before 1981 .

Figure 2 reveals a span of sustained patent activity at a relatively modest leve1. A majority of the period shows a rate of activity of 10-15 patents filed per year. Only in 1973 did the number of filings exceed 25. By way of comparison, the number of patents filed in photovoltaic cells, which is a new energy technology very close to rapid commercial development, exceeded 45 each year during the period 1975-80. The figure suggests continued interest in magnetic fusion without any dramatic shift in the level of patent activity.

\subsubsection{Activity Disaggregated by Assignee Sector}

Table 3 lists the number and percentage of patents issued to different types of assignees. Not surprisingly, the largest share of the patents issued 
ISSUE YHAR

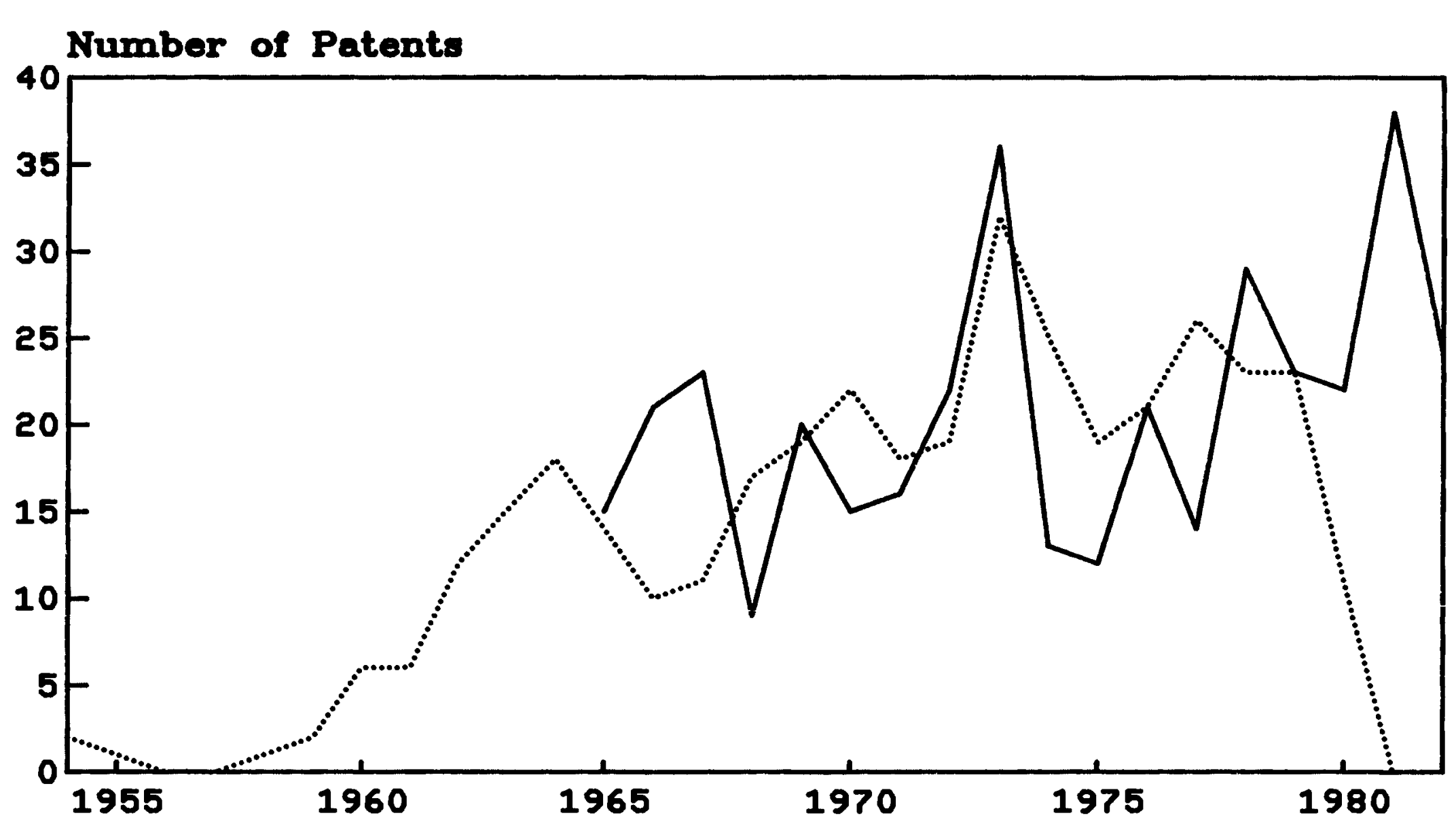

FIGURE 2. Magnetic Fusion Aggregate Patent Activity 
in this area were assigned to a government agency or laboratory, although private firms hold nearly the same numbers. The low number of patents assigned to universities is probably due to the fact that most fusion research performed at universities is under contract to government agencies. Patents developed during the course of such research would normally be assigned to the funding agency. It is somewhat surprising to see that nearly $12 \%$ of the patents were individually owned; i.e., issued to independent inventors. Apparently there is room for innovation in magnetic fusion from inventors without large organizational resources. The relatively low level of private firm/corporate sector patents is indicative of a technology far from commercialization.

\section{TABLE 3. Breakdown by Sector}

Sector

1 Private Firm or Corporation

2 University, College

3 Non-Profit Research Foundation

4 Government Agency or Laboratory

6 University Patent Broker

7 Individually-Owned Patent
No. of Patents

154

5

163

4

$\underline{44}$

TOTAL $\quad 373 \quad 100.0$

$\%$ of Patents

41.3

1.3

0.8

43.7

1.1

$\underline{11.8}$

Figure 3 plots the yearly activity disaggregated by assignee sector. University, research foundation, and patent broker assigned patents were combined as "other" for easier graphical interpretation. Except for the fact that 10 of the 12 patents in the "other" category were issued in the last 8 years, there are no apparent major trends (up or down) in the level of activity of the various sectors. Increased federal funding for fusion research from 1977-1982 has not as yet produced an appreciably higher rate of government assigned patents (Norman, 1983).

\subsubsection{Corporate Assignees}

A total of 58 private firms or corporations were assigned 154 patents, $41.3 \%$ of the total number of patents issued (see Table 3 ). Among these 


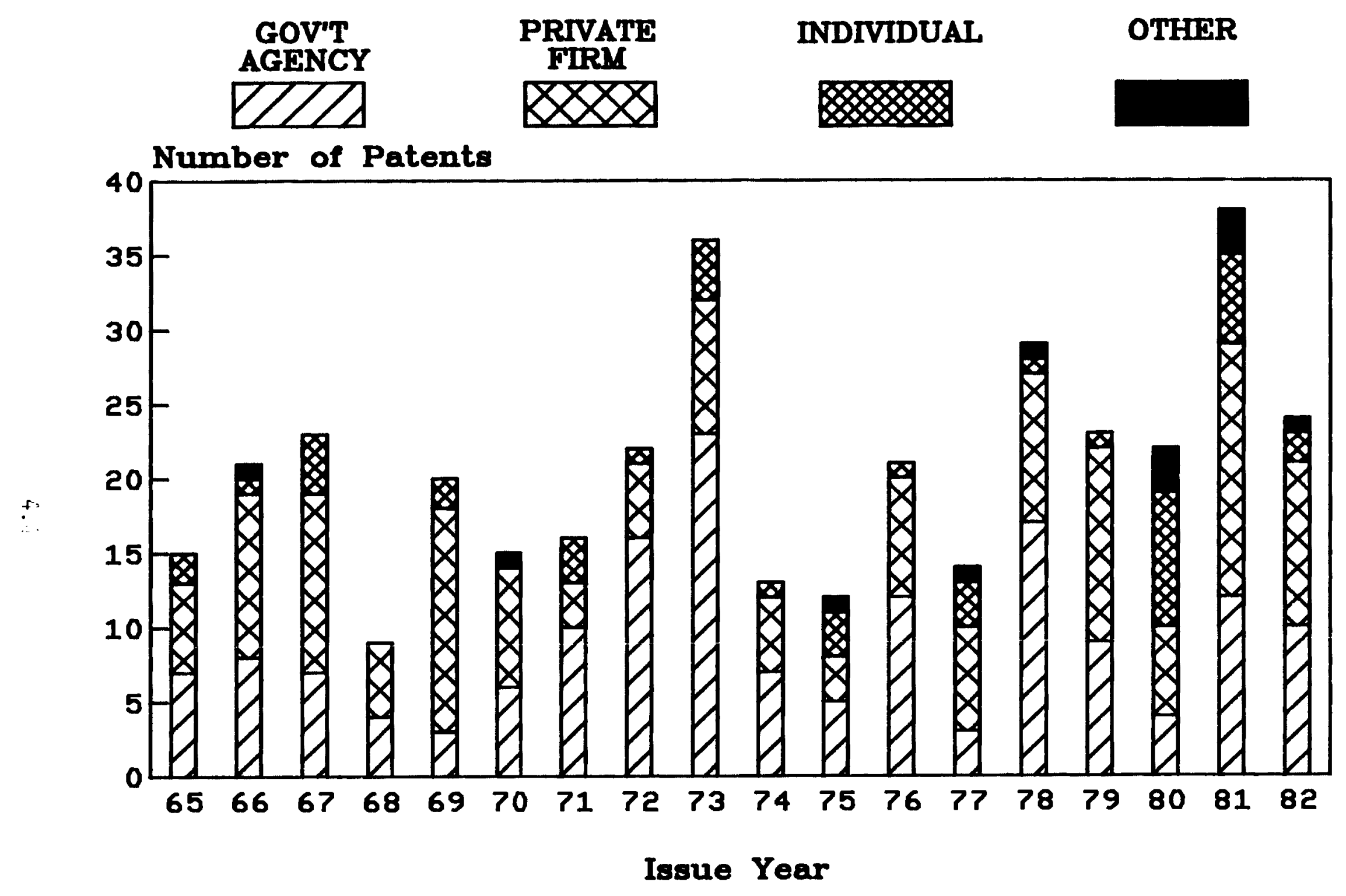

FIGURE 3. Patent Activity by Scope 
assignees, the top six most active corporations received $40 \%$ of this sector's patents. These six assignees are listed in Table 4. The top corporation -General Atomic -- has also worked as a contractor for the Federal government (inferred from the common inventor names). Therefore, truly independent work by corporates was probably responsible for 25-30\% of the total patents.

TABLE 4. Patent Activity for the Top Six Assignees

\begin{tabular}{lccc}
\multicolumn{1}{c}{ Top Corporate Assignees } & \# of Patents & & $\begin{array}{c}\text { \% of A11 } \\
\text { Corporate }\end{array}$ \\
General Atomic Company & & 9.7 \\
Texas Gas Transmission/KMS Fusion & 14 & 9.1 \\
TRW & 9 & 5.8 \\
International Telephone \& Telegraph & 8 & 5.2 \\
Siemens & 8 & 5.2 \\
Xerox & 8 & 5.2
\end{tabular}

\subsubsection{Activity Disaggregated by Country}

Table 5 lists the number and percentage of patents by assignee country (the inventor country is used when the patent is unassigned). The U.S. received $80.7 \%$ of the patents in magnetic fusion, considerably higher than the proportion of U.S. assigned patents across all technologies in recent years (OTAF, 1981). The remaining 19.3\% of the patents are distributed among 14 other countries, with France being the most active.

Figure 4 disaggregates the yearly activity by country. The figure shows that the number of foreign assigned patents per year has remained relatively constant, averaging close to four per year over an 18-year period. The leve 1 of U.S. activity has shown more yearly variation, although some activity occurred in each of the years studied. By contrast, West German activity declines after 1975. No foreign country shows any recent burst of major activity; however, the Japanese have received most of their patents in the last seven years. 
TABLE 5. Breakdown by Country

\begin{tabular}{ll} 
& \multicolumn{1}{c}{ Country } \\
01 & U.S.A. \\
54 & West Germany \\
55 & Japan \\
56 & France \\
57 & Belgium \\
59 & Canada \\
60 & Austria \\
61 & Italy \\
65 & Liechtenstein \\
67 & Switzerland \\
68 & USSR \\
71 & Australia \\
80 & The Nether lands \\
85 & United Kingdom \\
90 & Luxembourg
\end{tabular}

\begin{tabular}{rrr} 
\# of Patents & & $\%$ of Patents \\
\cline { 1 - 1 } 301 & 80.7 \\
14 & 3.8 \\
8 & 2.1 \\
24 & 6.4 \\
1 & .3 \\
2 & .5 \\
2 & .5 \\
2 & .5 \\
4 & 1.1 \\
1 & .3 \\
2 & .5 \\
1 & .3 \\
2 & .5 \\
8 & 2.1 \\
1 & .3 \\
\hline
\end{tabular}

$\begin{array}{lll}\text { TOTAL } & 373 & 100.0\end{array}$ 


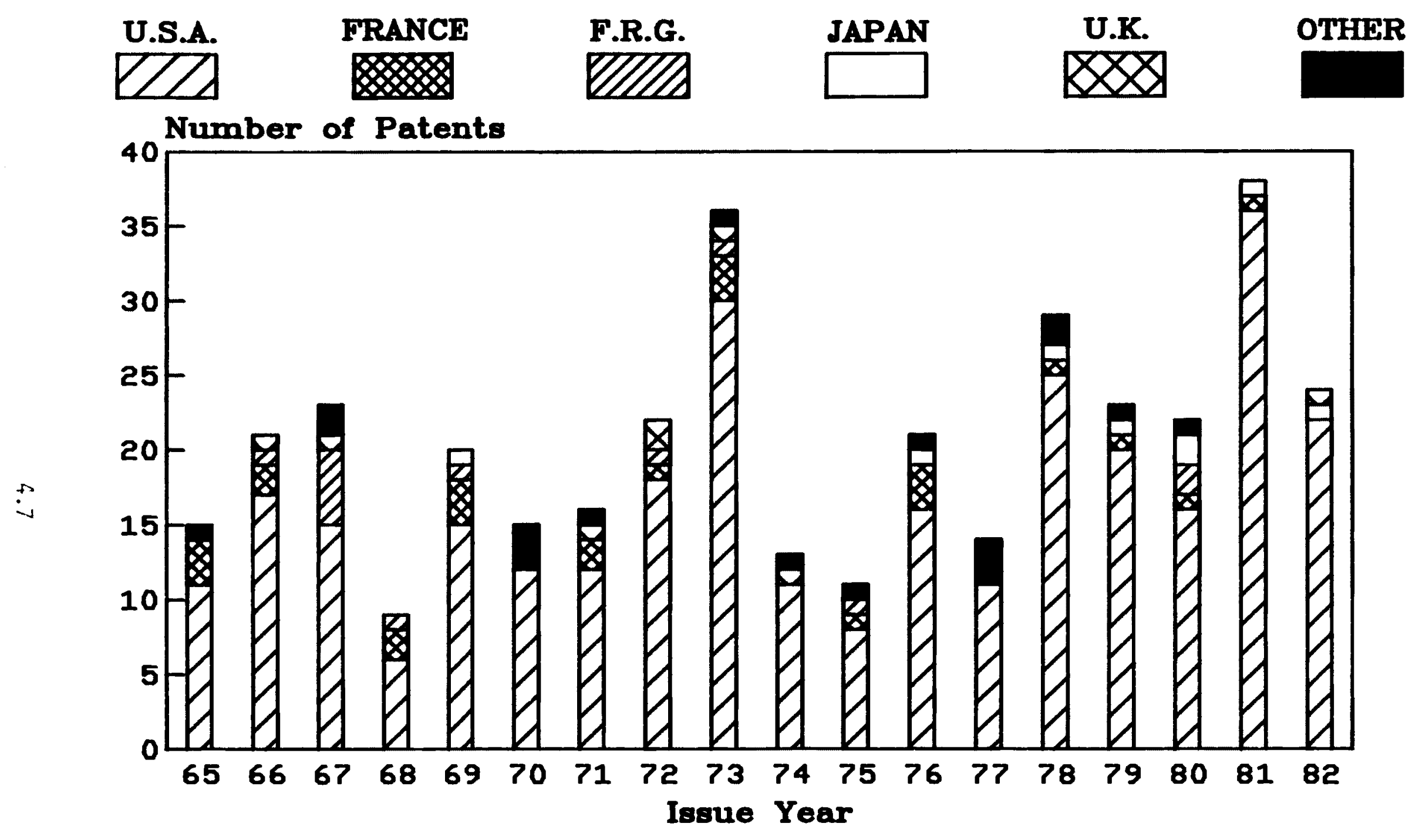

FIGURE 4. Patent Activity by Country 


\subsection{FUSION TECHNOLOGY TYPE COMPARISON}

Table 6 lists the number and percentage of patents by technology type. These categories are defined in Appendix A. Each patent was reviewed in depth before classification into one of the 14 types.

The three largest categories were heating, ion/plasma generation, and magnetic-field geometry. Together they include 251 patents, $67.3 \%$ of the total. This probably is an accurate reflection of the emphasis in fusion research. The fact that instrumentation/diagnostics, power conversion, and electrical equipment have relatively few patents provides additional evidence of a technology far from commercialization. While much of the relevant technology probably exists "off the shelf," more patents in these areas would be expected as the technology evolves to focus on engineering concerns.

\subsubsection{Technology Type Activity Trend Results}

Figures 5 and 6 show the yearly activity disaggregated by technology type. Note that Figure 6 is at twice the scale as Figure 5 to aid visual interpretation. Figure 5 reveals that the number of patents concerning ion/plasma generation is declining over time, particularly after 1974. By contrast, heating and field geometry show no decline. The other categories have appreciably fewer patents, making trend interpretation difficult.

\subsubsection{Technology Type Activity by Country and Sector}

Table 7 is a cross-tabulation of technology type by country. Generally, most foreign assigned patents are in heating (Type 05), confinement (Type 01), and plasma generation (Type 02), like the U.S.-held patents. However, in contrast to the U.S., which has patents in each category, foreign patents have noteworthy gaps. No foreign patents occur in plasma control (Type 03), boundary control (Type 04), process utilization (Type 10), and heat generation (Type 11). Moreover, several categories have only one foreign patent.

Table 8 is a cross tabulation of technology type by sector. Again, the same three categories receive the most patents across all sectors. It is 
TABLE 6. Breakdown by Techno logy Type

Techno logy Type

01 MAGNETIC FIELD GEOMETRY

02 ION, PLASMA GENERATION

03 PLASMA CONTROL/FEED SHAPING

O4 BOUNDARY/IMPURITY CONTROL

05 HEATING

06 COIL/MAGNET TECHNOLOGY

07 INSTRUMENTATION/DIAGNOSTICS

08 VACUUM TECHNOLOGY

09 TRITIUM BREEDING/PROCESSING

10 PROCESS USE OF FUSION ENERGY

11 BLANKET AND SHIELD DESIGNS

12 POWER CONVERSION/HEAT TRANSFER

13 ELECTRICAL POWER EQUIPMENT

14 MATERIALS
No. of Patents

86

64

13

10

101

20

11

3

22

15

10

13
$\%$ of Patents

23.1

17.2

3.5

2.7

27.1

5.4

2.9

.8

5.9

4.0

.3

2.7

3.5

1.1 


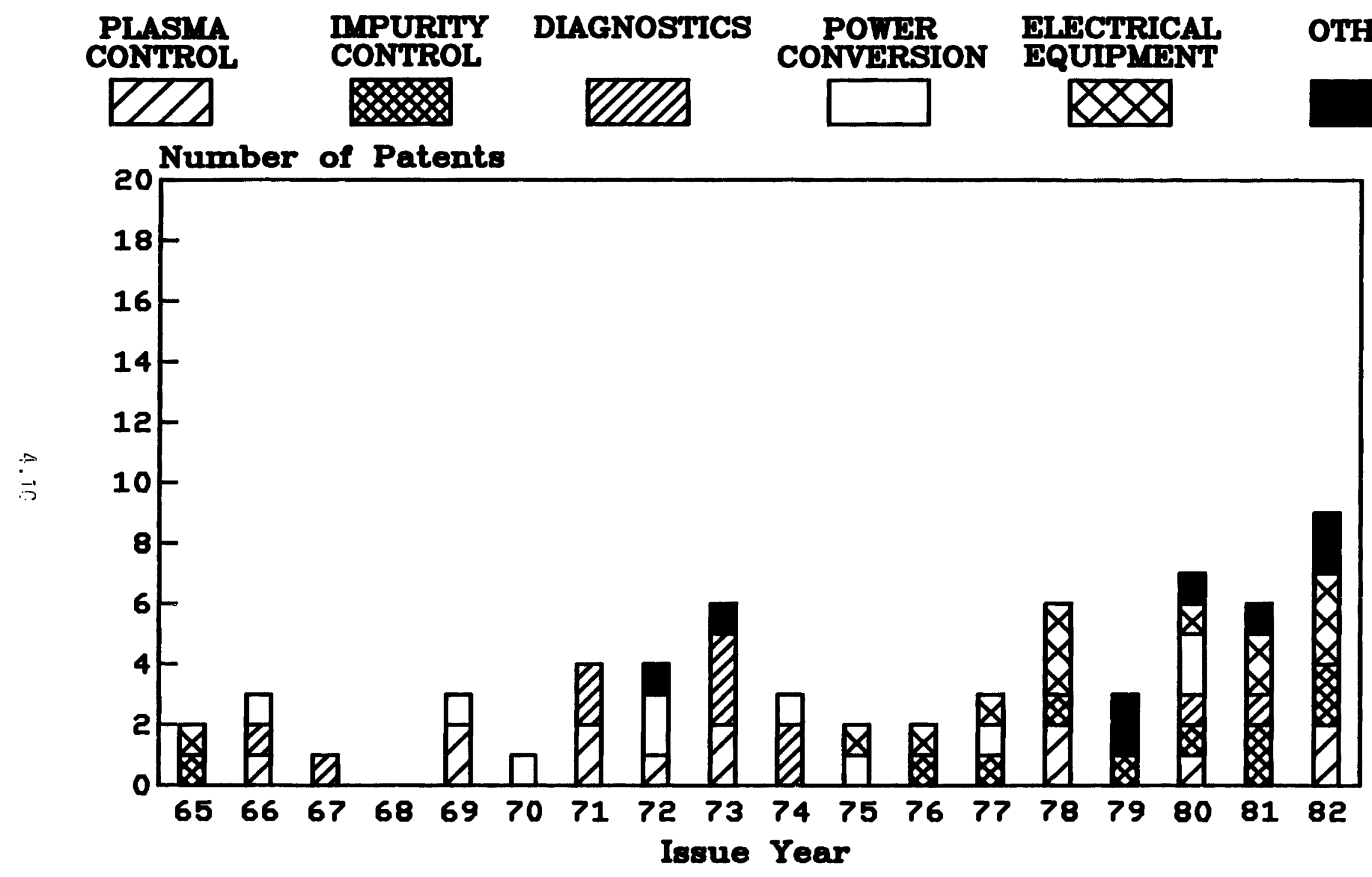

FIGURE 5. Patent Activity by Technology Type 


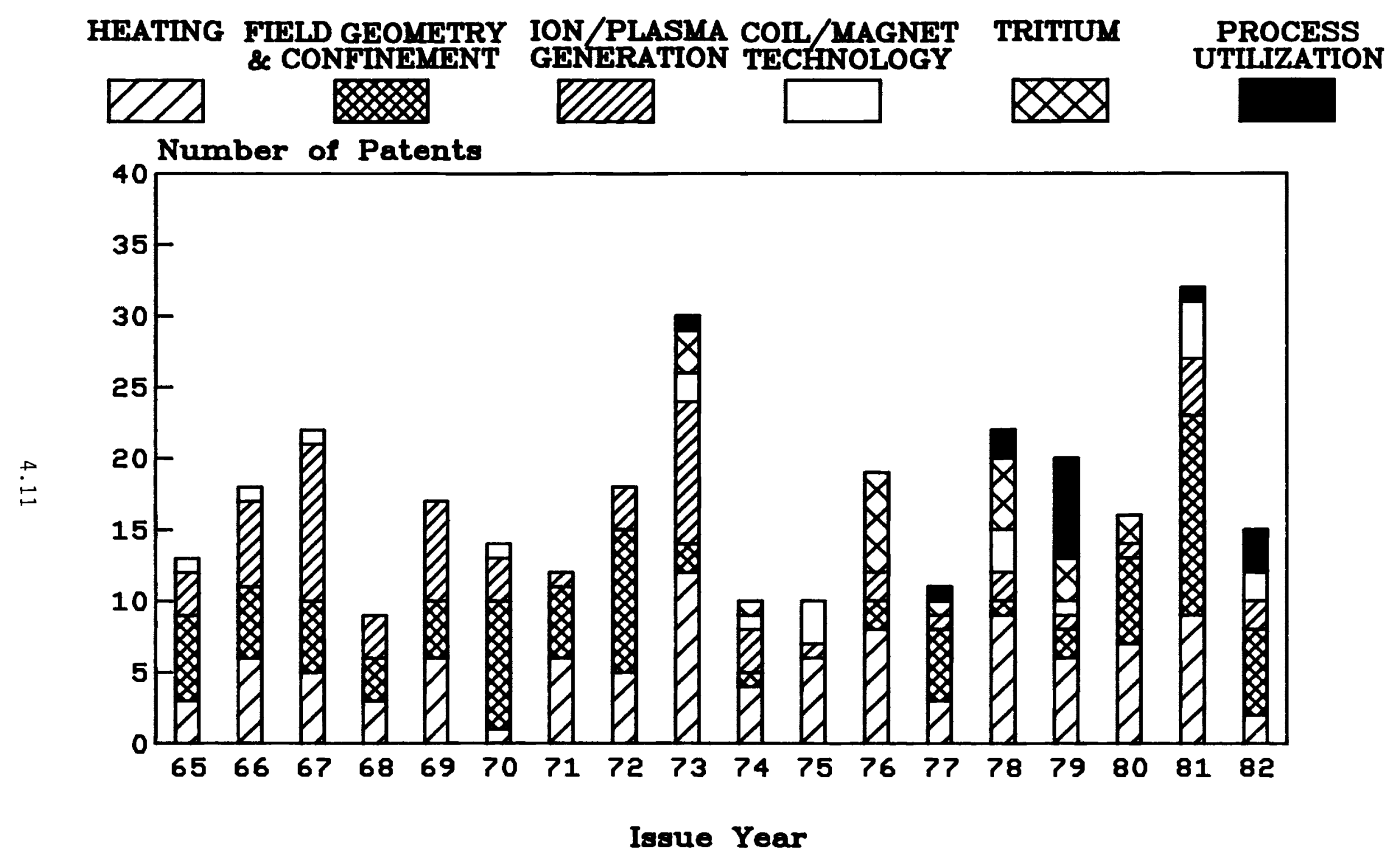

FIGURE 6. Patent Activity by Technology Type 
TABLE 7. Technology Type/Country Cross Tabulation

\begin{tabular}{|c|c|c|c|c|c|c|}
\hline Type & USA & France & Germany & Japan & UK & Other \\
\hline 01 & 70 & 4 & 1 & 0 & 4 & 7 \\
\hline 02 & 44 & 1 & 5 & 0 & 1 & 3 \\
\hline 03 & 12 & 1 & 0 & 0 & 0 & 0 \\
\hline 04 & 9 & 1 & 0 & 0 & 0 & 0 \\
\hline 05 & 81 & 5 & 7 & 3 & 1 & 4 \\
\hline 06 & 18 & 0 & 1 & 1 & 0 & 0 \\
\hline 07 & 9 & 1 & 0 & 0 & 1 & 0 \\
\hline 08 & 1 & 0 & 0 & 1 & 0 & 1 \\
\hline 09 & 18 & 1 & 0 & 1 & 0 & 2 \\
\hline 10 & 15 & 0 & 0 & 0 & 0 & 0 \\
\hline 11 & 1 & 0 & 0 & 0 & 0 & 0 \\
\hline 12 & 9 & 0 & 0 & 1 & 0 & 0 \\
\hline 13 & 11 & 0 & 0 & 1 & 1 & 0 \\
\hline 14 & 3 & 0 & 0 & 0 & 0 & 1 \\
\hline TOTAL & 301 & 24 & 14 & 8 & 8 & 18 \\
\hline
\end{tabular}


TABLE 8. Technology Type/Sector Cross Tabulation

\begin{tabular}{|c|c|c|c|c|}
\hline Type & Government & Private & Individual & Other \\
\hline 01 & 33 & 34 & 13 & 6 \\
\hline 02 & 24 & 30 & 9 & 1 \\
\hline 03 & 8 & 3 & 2 & 0 \\
\hline 04 & 6 & 4 & 0 & 0 \\
\hline 05 & 55 & 31 & 13 & 2 \\
\hline 06 & 10 & 7 & 2 & 1 \\
\hline 07 & 6 & 4 & 0 & 1 \\
\hline 08 & 1 & 2 & 0 & 0 \\
\hline 09 & 6 & 14 & 2 & 0 \\
\hline 10 & 2 & 13 & 0 & 0 \\
\hline 11 & 1 & 0 & 0 & 0 \\
\hline 12 & 6 & 2 & 1 & 1 \\
\hline 13 & 3 & 9 & 1 & 0 \\
\hline 14 & 2 & 1 & 1 & 0 \\
\hline & 163 & 154 & 44 & 12 \\
\hline
\end{tabular}


interesting to note, however, that corporate assignees have a greater relative emphas is in tritium breeding (Type 09), process utilization (Type 10), and electrical power equipment (Type 13). Also, the other corporate patents cover the remaining 14 areas with nearly the same overall distribution as appears for government patents.

\subsection{A SUMMARY OF RESEARCH FINDINGS}

A total of 373 U.S. patents were analyzed in this study. The principle findings of the research are sumarized below:

- Fusion patent activity has been generally stable in most years since 1965 at the relatively modest level of 10-15 patents per year. No major trends in patent volume, either up or clown, were apparent in the data.

o The 1 argest share of U.S. patents have been issued to either an agency (or laboratory) of the U.S. government (43.7\%) or a private firm or corporation (41.3\%). Also, a surprisingly high percentage (12\%) of the patents are held by independent inventors.

O U.S.-held patents comprised $80.7 \%$ of a 11 patents compared to foreign assignees. France (6.4\%) and West Germany (3.8\%) are second and third in activity respectively. Furthermore, no foreign country shows any major recent burst of activity. However, most of Japan's patents (2.1\%) have been issued since 1977 .

o The three largest technical areas of patent activity have been heating, ion/plasma generation, and magnetic-field geometry technologies. In fact, these areas dominate the 14 categories analyzed with $67.3 \%$ of all patents. Of these three areas, only ion/plasma generation patent activity seems to be decreasing; the other two major areas are relatively stable.

o Most foreign patents also occur in the same three technical areas identified above. 
- Also, most privately held U.S. patents are also concentrated in the three technical areas previously mentioned. However, corporate assignees have a greater relative emphasis than all other assignees in tritium breeding process utilization and electrical power equipment patents. 


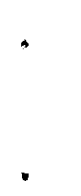




\subsection{RECOMMENDATIONS FOR FURTHER RESEARCH}

The major purpose of this research was to provide recommendations as to the need for and nature of additional fusion patent research. The key findings in this analysis of general patent characteristics confirm that fusion technology is at a very nascent stage of development, but do suggest some value for the role of patent analysis in R\&D program management. The major results of this analysis are as follows:

o No dramatic change in the aggregate level of patenting has occurred in the last five years.

- Patents assigned to the U.S. government constitute a majority of the patents identified. However, a surprisingly high pecentage of independent patents are held.

- Foreign assigned patents represent about $20 \%$ of the patents identified of the foreign assignees, Japanese and French patents show the most recent sustained level of activity.

o Confinement, plasma generation, and heating have remained the primary thrusts of patent activity research since 1965 across all the assignee sectors.

Given these results, any further patent analysis should focus on issues which would aid in the planning of future magnetic fusion research, e.g., scientific and technical productivity of funded research organizations, recent shifts in technical focus, justification of funding priorities, or identification of spinoffs from fusion research to other areas. Both the content and timing of patent data are useful contributions to understanding these issues -particularly when combined with other types of data -- to form multiple indicators of R\&D progress and its sources. For example, in program evaluation studies, patent data would be a valuable supplement to expert judgement for assessing research significance and productivity (DOE, 1982). 
In planning R\&D programs, patent data is a rich source of information on innovative concepts. Patents are also a good indicator by which to monitor progress of relevant organizations and it is particularly valuable to monitor foreign competition. Using patent citation analysis, spinoff developments and key work in related technical areas can be identified. To illustrate how these issues can be addressed, two general types of recommendations are given.

\subsection{EXPANDED PATENT ANALYSIS}

Further detailed technology analysis using pattents should focus on the areas of confinement, plasma generation, and heating. The other technology categories have too few patents for meaningful trend analysis. These three areas, with approximately 250 patents, represent a relatively small but still analyzable patent set.

Patent reference and citation analysis is an important technique which was not used in this preliminary study. Citation data would be useful to permit more in-depth analysis of the linkages between technical areas, inventors, and assignees (Campbell, 1983). Highly cited patents not included in the initial list of patents should be identified for possible inclusion in a more complete patent set, particularly any patents issued before 1965. This will give a more complete picture of the evolution of this technology. Highly cited patents and inventors could be used to identify the source of significant developments.

References to fusion patents from patents outside the study set are valuable for identifying spinoffs from fusion research to other areas. This type of analysis is covered by the Battelle patent indicator Generality (Campbell and Nieves, 1979).

An analysis could also be made to identify the specific laboratory, university, or corporate contractor where work was done to produce government assigned patents. This information can be used to disaggregate the analysis at a level more useful to determining the significance of research progress and the outlook for research organizations or approaches -- which may aid technical planning decisions in budget-constrained fusion research programs. 


\subsection{BIBLIOMETRIC STUDIES}

Clearly, magnetic fusion development is tied to advancements in both theoretical and applied science. Patents, by themselves, do not capture the full scope of these activities. Thus, to strengthen the understanding of fusion development trends, further patent analysis should be supplemented with a bibliometric analysis of articles and reports in the same three areas of magnetic fusion technology (Irvine \& Martin, 1983). These articles would be identified in the U.S. DOE Technical Information Center (TIC) data base and then acquired. The bibliometric information on these articles in the A copy of the TIC data base can be augmented with the references listed in each article or report to permit a more indepth analysis.

With a bibliometric data base, highly cited articles and authors could be identified. Citations among articles could then be used to identify clusters of articles and the technical approaches they represent with the same techniques presently used for the Battelle patent analysis studies. Linkages between clusters are helpful to identify where "cross fertilization" of ideas is occurring. An attempt to correlate highly cited authors and inventors would be useful in identifying technical leaders in magnetic fusion research. 


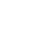

. 


\section{REFERENCES}

Campbe11, R. S. 1983. "Patent Trends as a Technological Forecasting Tool." Wor ld Patent Information. 5(3):137-143.

Campbe11, R. S. and A. L. Nieves. 1979. Technology Indicators Based on Patent Data: The Case of Catalytic Converters. Prepared for the National Science Foundation under NSF Grant PRA 78-20321. Battelle, Pacific Northwest Laboratories, Richland, Washington.

Carpenter, M. P. et a1. 1980. "Linkage Between Basic Research Literature and Patents." Research Management. 13(2):30-35.

Conn, R. W. 1983. "The Engineering of Magnetic Fusion Reactors." Scientific American. $54: 61$.

Irvine, J. and B. R. Martin. 1983. "Basic Research in the East and West: A Comparison of the Scientific Performance of High Energy Physics Accelerators." Submitted to Social Studies of Science.

Norman, C. 1983. "Boom and Bust in Energy." Science. 221(4609):443.

U.S. Department of Energy, Office of Energy Research. 1982. An Assessment of the Basic Energy Sciences Program. DOE/ER-0123. Vol. I.

U.S. Department of Energy, Technical Information Center. 1983. Fusion Energy Update. CFU-83/4. Oak Ridge, Tennessee.

U.S. Patent Office. 1972. General Information Concerning Patents. U.S. Government Printing Office, Washington, D.C.

U.S. Patent and Trademark Office. 1981. Manual of Classification. U.S. Government Printing Office, Washington, D.C.

U.S. Patent and Trademark Office, Office of Technology Assessment and Forecast. 1981. Technology Assessment and Forecast: Tenth Report. U.S. Government Printing Office, Washington, D.C. 



\section{APPENDIX A}

MAGNETIC FUSION TECHNOLOGY

TYPE CATEGORIES

A. 1 
.

. 
APPENDIX A

\section{MAGNETIC FUSION TECHNOLOGY}

\section{TYPE CATEGORIES}

\section{Magnetic Field Geometry and Confinement Schemes}

This category would include all of the open and closed field line configurations for confining a plasma. Note that some devices such as the tokamak produce a plasma as part of the start-up operation. Others consist of the filed configuration alone. Keywords: Toroidal confinement, mirror devices, linear confinement.

2. Ion, Plasma Generation

This category would include devices designed for the generation of plasmas, which are then injected into the confinement device, or used in some other fashion. (Sources used to heat other plasmas are called out separately under Heating below).

3. Plasma Control/Field Shaping

This category would include mechanisms for the control of the plasma and field configuration during operation. This includes feedback and stability control.

4. Plasma Boundary/Impurity Control

This category would include devices such as divertors and limiters which are used to control the outer boundary of the plasma and its interaction with the material walls of the vessel. These devices can consist of a localized modification to the field lines and a material object or device of some sort to subsequently trap ions directed to it, and limit backstreaming of ions or sputtered material to the plasma.

5. Heating

This category includes methods for heating plasmas which have al ready been created (see Categories 1 and 2 ). This can include particle beams, radio 
or microwave frequency radiation, or lasers. Also included here are schemes for shockwave or explosive compression heating of plasmas (Imploding Liner).

6. Coil/Magnet Technology

This category includes normal and superconducting magnet technology. This includes the windings themselves, as well as radiation shields, dewars, etc.

7. Instrumentation/Diagnostics

This category includes devices, techniques, etc., for analyzing, sensing, measuring of plasma parameters or conditions in the fusion device.

8. Vycuum Technology

This includes mechanisms for vacuum vessels, pumping, valves, flanges, seals, etc.

9. Tritium Breeding/Extraction/Recovery/Processing

Fusion reactors based on the deuterium-tritium fuel cycle typically include provisions for breeding tritium in the blanket of the reactor surrounding the plasma. Lithium or lithium compounds are typically used. This category includes those areas of compound preparation and location in the device, as well as the necessary technology to recover, extract, and isotopically purify the fuel stream.

10. Process Utilization of Fusion/Plasma Energy

This category includes devices, processes, et:c., which utilize the fusion energy for inducing or accelerating chemical reactions or materials production.

11. Heat Generation/Blanket and Shield Designs

In fusion reactors based on a thermal heat cycle to genrate power, the plasma radiation must be converted to heat. This category includes devices, schemes, etc., to convert the kinetic energy of streaming ions and neutrons to heat. Note that this is often closely related to tritium production. 
12. Power Conversion, Thermodynamic Cycles

This category includes coolants and working fluids, etc., for the transport of heat and devices for conversion of heat to other energy forms (i.e., electricity). Direct conversion of the kinetic energy of streaming ions to electricity is also possible in this category.

13. Electrical Power Supplies/Power Storage/Switching/Transmission

This category would include devices required to store, switch, and deliver high megawatt power levels to fusion devices. Storage devices incude flywhee ls and capacitors. Special transmission lines are often needed to handle the power levels involved.

14. Materials

A category for materials or advances in material science is included. Materials in the vacuun vessel facing the plasma are of primary concern. 
APPENDIX B

A LISTING OF MAGNETIC

FUSION PATENTS

B. 1 
PAGE NO. 00001

PATENTI ISSUED FILED

TITLE

ASSIGNEE

SE 00 TY

CT UN FE

3166477190165071259 INUECTION SYSTEM FOR FIXCTRIC DEVICE

3170041230265140754 PYROTRON THEPMONUCIEAR RFACTOR AND PROCESS

3171780020365170563 ROTATING PLASMA DEVICE

3174068160365190460 PIASA OONFINING DEVICE

3177408060465180961 SUPEROONDUCTOR SOLENOID WITH OVERHEAT PROTTCTIVE STPQCCIURE AND CIRCU

3189523150665270361 MEANS POR PRODUCING HIGI TFMPERATIRE PIASMA

3191092220665200962 PLASTA PROPULSION DEVICE HAVING SPECIAL MAGNEI'IC FIELD

3194739130765200862 FUSION RESEARCH APPARATUS

3200268100865201161 HIGH CURRENT GENERAIOR ARRANGPMENT

3212974191065310560 PAPRTCLE INJECTING DEVICE

3214342261065220661 PROCESS POR PRODUCING INIFNSE MAGAN

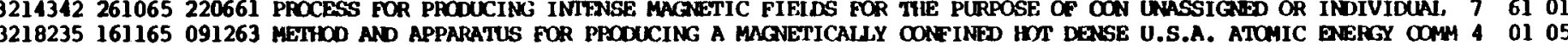
3218562161165200862 MEIIIOD AND APPARATUS FOR ACCEIERATION OF CHARGED PARTICIES USING A L UNASSIGNSD OR IMDIVIDUAL 7 OI 05 3219534231165261064 PIASMA OONFINEMENT APPARATUS EMPLOYING A HELICAL MAGNETIC FIETD OONF U.S.A. ATCMIC ENERGY OOMM 4 Ol O1 3222559071265111264 PRODUCTION OF CONPI r.TELY IONIZED PLASMA

3230145180166041163 APPARATUS FOR MAGNETICALIY CONFINING A PLASMA

3230418180166230661 DEVICE HAVING HIGH-GRADIFAY MAGETIC CUSP GEOMETRY

3232046010266060662 PIAGM GENGRATOR AND PPOFIISION EXXAUST SYSTEY

3238414010366280765 HIGH OUIPUT DUOPLASTAT11ON-IYPE ION SOURCE

3244969050466201263 ELECTRON ORBITING TUBES FOR ION

3256687210666310758 HYDFOMAGNETICALYY OPCRATTED GAS AOCFJ ERATIOK PFOPUISION DEVICE

3256687210666310758 HYDFOMAGNETICALLY OPFEATED GAS AOCFI

3257283210666210863 METHCDS OF HEATINA JONL IN A PIASMA

3257579210666070460 PARTICIE-CONFINING DEVICFS ILAVING MAGNETIC MIRRORS

3258401280666230762 FUSION-RESEARCH APHNRATUS

3258402280666110162 ETACTRIC DISCTIARGE DEVICE: FOR PROOUCING INIERACTIONS BETWEEN NUCTEI

3260869120766210262 METHOD FOR REVERSIBLIY FXTRACTING ENEPGY FTIM A PI ASMA BY MAGNETIC PU

3265583090866140464 APPARATUS FOR PRODUCJING AMD PURIFYING PLASMA

3270236300866060364 ET.DCTRODFI.SSS APPARATUS FOR PPODUCING OR AOCEIERATING PIASMOIDS

3274435200966160260 METHOD OF INJECPING NII TRAPPING PARI'ICLES IN A SIATIC MAGNETIC OON

3278384111066130465 NECATTVE - $V=$ STELLAKATOR

3279175101066191262 APPAFATUS FOR GEMERATIING NO NOCEIERATIING CIARGED PAKIIICLES

3286162151166230763 METHOD OF POIARIZING IONS, AND SOURCES OF POIARIZED IONS, NOTABLY PR

3290219061266190963 PLAGMA CONIAINMENT BA:T1DO MAD APPARATUS

3293583201266170761 TOROIDAL INUUCTOR

3298179070167121163 CONFINAD PAPNILEI, RAIL PUISED PLASMA ACCF1FRAIOR

3300640240167130564 MEANS FOR MENSURING PINSAM DENSITY MY RFGONNM CHATGE: IRANSFER WITH

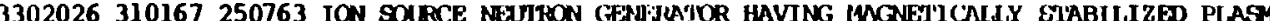

3303097070267200865 HIGH-PRFSSURE AND -T1.MPERATURE GENERATOR

3303449070267280262 TOJOIDAL MAGETIC COFNS HAVING VARYING CPOSS-SBCTIONAL APEAS

3305448210267060563 INIRODUCTION OF FUE. 1NIO A THEIMONUCLFAR RFACTOR

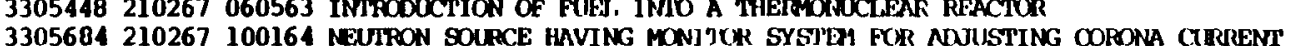

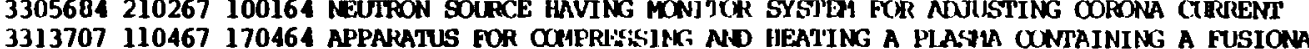

3315114100467050262 PIASTA COMTAINMENT APPANAITS OOMPRISING ROTNTING AND FIXED MAGNETIC

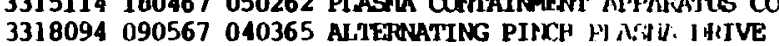

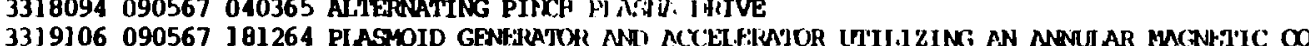

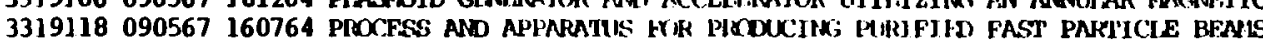

COMPAGNE GENERALE DE TFL 15604 U.S.A. ATOMIC ENERGY OOMM 4 0101 U.S.A. ATOHIC ENERGY COM 4 al 01 OMPAGNIE GENERALE DE TEI, 156 ol U.S.A. ATCIIC ENERGY COMM 4 0106 D. U.S.A. ATCAIC ENEARY COMA 4 OI 02 GENERAL DYNAMICS CORP. 1 ol 01 THE AEPOSPACE CORPORATI MNASSIGASD OR INDIVIDUAL 7 ol 05

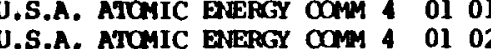
U.S.A. ATONIC ENERGY COM 4 ol 01 U.S.A. ATONIC ENERGY OOMM 40101 THE AFPOSPACE CORPORATION 1 ol 02 U.S.A. ATOHIC ENERGY OOMH WISC. AIRIT ENS. POROAT 6

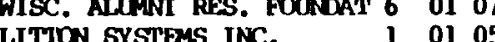
AVOD STSTMS INC. 1 o1 05 ANOO HANTFACTURING CORP. 1 l 0105 Cart .s.A. Manic Davera com 401 o COFPAGNE GANERALE DE TEL 15601 GENERAL DYNAMICS COPP. 1 o1 01

U.S.A. MTMIC FNERGY OOMM 4 ol 12 U.S.A. ATOHIC ENERGY OONH 40102 SI BMENS-SCHUCKERTWERKE AK 15402 GENERAL DYNAMICS OORP. 1 ol 05 J.S.A. ATONIC DFFrGY OOMM 40101 RADIO CORPORATION OF AMER 1 01 02 OCMMISSARIAT A L'EAERGIE l 5602 GENEPAL BIECTRIC COMPANY 1 01 05 UNASSIGNED OR INDIVIDIALL 7 01 06 ROCKET RESFARCH CORP. $\quad 1 \quad 0102$ U.S.A. ATOHIC ENERGY COMM 4 01 07 ESSO PRODUCTION RESEARCH 1 ol 02 UNASSIGNED OR IRDIVIDUAL, 7 ol 01 U.S.A. SEC. OF TIIE NAVY 40106 KEPAREFAKIOR BAU- UND BETR 1 54 05 DRESART INDUSIRI ES INC. 1 ol 02 UNITED KINCDOM ATDNIC ENE 4 85 01 SIEMENS-SCIUCKEPAWEIKE AK 15402 U.S.A. ATOMIC ENERGY OOMN 4 ol 05 
3321664230567100864 PLASA AOCETEFATIOR HAVING RAPIDLY PULSED COII, FOR EXPELIING PLASMA 3321919300567090764 APPARATUS FOR GEJAERTIING HIGH DENSITY PLASMA

3324316060667 OB0664 CONITOLIED FISION DEVICES

3326769200667200766 ENEPRCBTTC ELJECTRON PIAST IN BIANTET

3338788290867220162 APPARAJUS FOR PROOKCING IIIGH INIENSIIY MAGNETIC FIEIDS FOR USE NN $\infty$ 3338789290867200865 FUSION GENERATOR OF HITH IMTENSITY,PUISLD NEUMRONS

3345524031067230965 MEIHIOD AND APPARATISS FOR ENERBGY OONVERSION

3346458101067 070864 PROCESS AND APPAPATUS FOR PIACIYK MAIERINIS IN A STATE OF PIASMA

3353107141167061059 HIGH VOLATGE PAKTICIE ACCELERAIORS USING CIARRE TRANSFER PROCESSES

3359422191267281054 ARC DISCHARGE AJOMIC PARIICLE SOURCE FOR TIE PRONUCTION OF NEUTRONS

3360692261267221264 DEVICE FOR PPOOUCING HIGI-INTENSITY MAGNETIC FIEIDS OF SHORT DURATIO

3361634020168161162 PLASMA METHOD ANA APYNNATIS FOR GETERATING ENERGY

3363130090168231065 FREQUENCY TUIING OF AN ENERGETIC ARC DISCILARGE BY VARYING THE DIAMET

3369140130268011063 ANWIIAR ONNINEMENT OF HICH TEMPERATURE PIASALAS

3374629260368280765 HIGH EFFICIENCY PARALET RAIL AOCFIEIRATOR

3376469020468300965 POSITIVE ION-SOURCE HAVING ELECTTON RETAINING MENN

3386803040668130566 METHOD AND APPARAITS YOR PRODUCIN: NICIEAR-FUSION REACTIONS

3387174040668180767 MEIHOD AND APPAKATLIS FOR RFONIMG IMPURITY GAS PARTICIES FROM A PART 3400527291068120664 HIGI ENERGY PJASTA OONIAINMENI DEVICE UTILIZING AITERNATE $Z$ AND O PI 3418206241268080464 PARTICLE ACCFJERATTOR

3425902040269090367 DEVICE FOR THE PRODKCTION AND OONFINEMENT OF IONIZED GASSES

3426233040269131265 PLASMA SIABILIZATION BY NOTATION OF ARC DISCHAIXE TIIIE.

3431461040369180163 EIDCTRON CYCLOMTON RESONANCE HEATING UEVICE

3433705180369280268 STEZIARATOR HAVING MUITTIPOIE MAGNEIS

3437862080469230555 MEAHOD AND APPARAT'LS FOR PPOOUCING HIGI 'IERIPERATURES BY A MAGNETIC 3437871080469270466 PLASMA ONNIAINMENI APF'NLATUS WITH ION CYCLOTTON RESONMNCF. HEATING

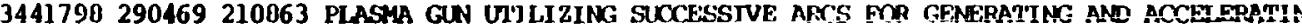
3442758060569070863 OONTAINMENT OF A PLAS1A HY A ROTATING MAGIETIC FIEID

3445333200569011266 PROCESS FOR T11: PKOOKCIJON OF ENIERGY BY CONIYOILED FUSION

3445722200569041164 PLASTA MANIPUILATTON MEITTCD AND APPARATUS

3449628100669270466 PLASHA NKC ETECTROH'S WJTI ANOUE HEAT SIIEID

3452249240669210565 METHOD AND APPARATUS FOT (XNTAINING A PLASMA PIROUCEI) BY OPPOSED EIJE

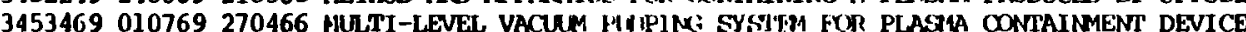

3453474010769270466 PLASMA ARC ET.BCIXYNES

3453488010769200565 PLASTA ARC ELLXTRODES

3453489010769200565 MULTIPIE ANDOE EJ.HXYIXOE ASSFMBIY

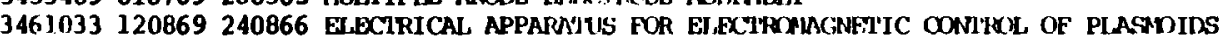
3462622190869270466 PIASTI ENEHKY EXTRACT'ION

3467885160969200565 HETHOD AND APIARATIS FOH EIEXIROMAGNFIICALIY CONIAINING A PIASMA

3465716231269011167 METHOD AND APINAATUS FOR INCTECTING NO

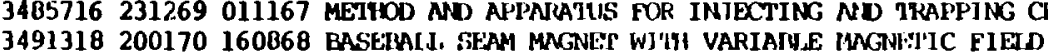

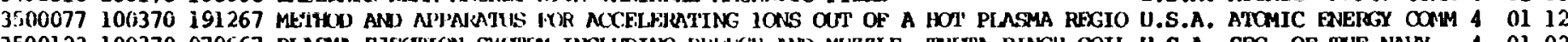

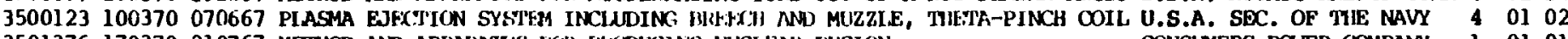
3501376170370210767 METILO AND APPNRATIS FC PHODUCIFX NUCIPNI FUSION

3508104210470030767 APPARATTS FOR TIE STAHIF CONFINIWIENI' OF' A PLASAMA

351335] 190570260668 DUOPIASMATRON-TYPE' ](N GOXIXE IMCLADING A GAS RFSSFINUIR

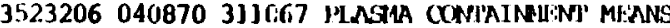

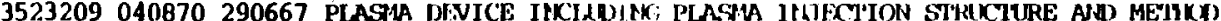

U.S.A. ATOMIIC ENERGY OOMM 4 Ol 02 HIGH VOLTAGE ENGINEFTING 1 Ol 02 ELECTFO-OPTICA. SYSTEMS 1 ol 01 U.S.A. ATOMIC ENERGY OOMM 4 0101 DUROPEAN ATCMIC ENERGY 0045705 GDNERAL DYNANICS OORP. 11 0] 01 UNASSIGED OR INUIVIDUAL 7 5402 HIGI VOUTAGE GNGINEERING 1 0102 GENERAL EIDCIRIC COMPANY 1 O 0102 J.S.A. ATOMiC enERry Oan 40102 U.S.A. ATOMIC ENERGY OOMM 4 ol 01 HUGIES AIRCRAFT COMPANY 1 01 02

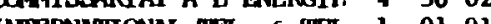
INERANATIONAL TWT. \& TFJ.. 1 ol 01 IPRENS AKTT ENGESEIISCTIAF i 5401 THE BOEING OOMPANY $\quad$ 1 01 05 OCMMISSARIAT A L'ENERGIE 45605 VITPO CORPORATION 110103 KABUSHIKI KAISIU HITACHI 15505 U.S.A. ATOMIC ENERGY OOMM 1 ol 01 XEROX CORPORATION

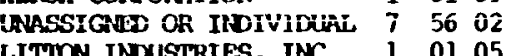
LITTON INDUSTRIES, INC. 1 ol 05 GUIF GENERAL ATOMIC INC. 1 ol 02 XEROX CORPORATION 1 ol 02 EIFCTRO-OPIICAL SYSTEMS 1 01 02 XEROX CORPORATION 1 ol 02 XEROX CORPORATION 110102 XEROX CORPORATION $\quad 1$ ol 02 $\begin{array}{llll}1 & 01 & 02 \\ 1 & 01 & 02\end{array}$

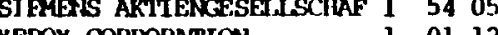
XFFOX CORPONATION 1 o1 12 X 1

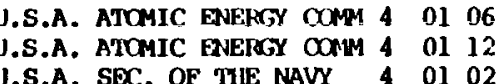
CONSUMERS POWER COMPANY 1 0] 01 STICTITING VOORFUNOAMENIEE $3 \quad 80$ 0] U.S.A. ATOMIC DAE:TGY COMM 4 0102 ENIPOFY LIFIITED 115901 SIEMENS-SCHUCKERTWERKE AK 1 54 02 


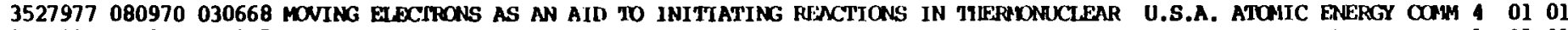
3530036220970151267 APPARATUS FOR GrNERATING FUISION REACIIONS 3530497220970240468 APPAPATUS

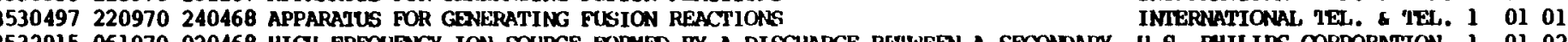

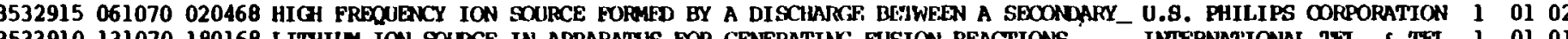
3533910131070180168 LITHIU, ION SOURCE IN APPARATUS FOR GENERATING; FUSION REACTIONS INIFIPRATIONAL TET. \& TES. I O1 OI

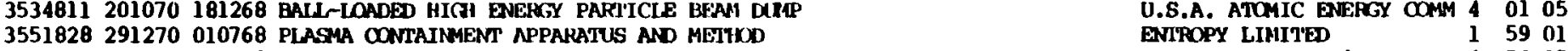

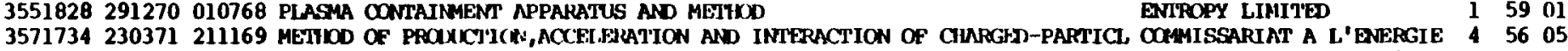

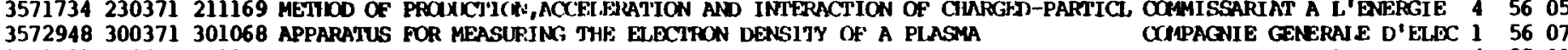

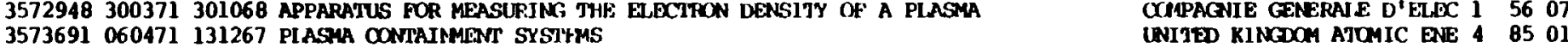
357559820047210268 PLASMA SIMUIATION ANI ANULYSIS APPARATUS AND METHOD 3577026040571062469 METHOD FOA PROOUCING JONS UTILIZING A CHARGE-TPANSFER OOLLISION 3577317040571010569 CONITOLLED FUSION REACTOR

3579027180571040368 IGNITING AID FOR HIGI EFFICIFANCY PIASHA PROMXCERS

3579028180571231068 OONVERGING-BAFRPJ, PLASPIA ACCETERATOK

TFW INC.

10103 U.S.A. ATOMIC ENERGY OOMM 4 Dl 05 U.S.A. ATOMIC ENERGY OOMM 4 Ol 01 GEBR. BOHLER \& OO. AKTIEN 16002

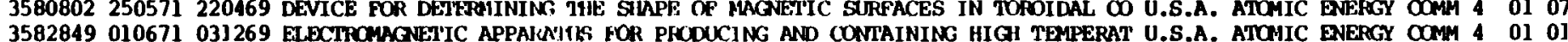

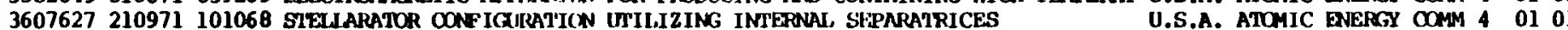
36] 4525191071140169 PLASTA COPRFSSION APPAFATTS 3624240301171240370 FEEDRACK STABILI ZATION OF A MAGNETICALLY OONFINFJ PIASMA 3624443301371310870 TWO-PLASMA GUN RAACIITTC: FIITD LOADIIKG METHOD

3626305071271270169 HIGH ENERGY ION ACCEIIFISATOR

3643123150272281068 PLASA CONTAINMFI DEVICE

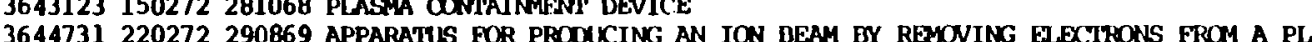

3649862140372010569 STPAPATED IOA PRAM GOUG AN ION BEAM BY REFONING EA.ECTRC

3650893210372021269 PORT PLUG FOH A YIMTHA-CYNFINING CAVITY

3650893210372021269 PORT PLUG FOW A PIASTA-CYNFINING CAVITY

3655508110472120668 ELECIROSTATIC FIEID APPNPATUS FOR REIUCING IFAKAGF, OF PINSMA

3657542180472040570 PRODKCTION OP BEAMS OF EXCITED ENERGFTIC NEUI'RAL, PARTIICIES

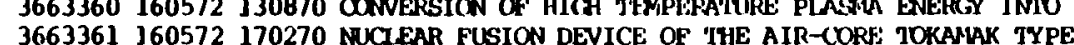

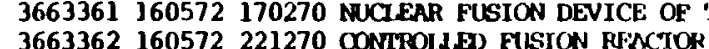

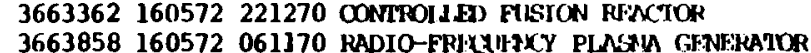

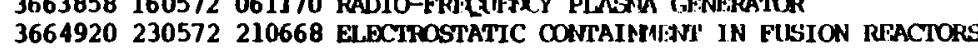

3664921230572161069 PROTON E-LAYER ASITKON FOR PHODUCING CONIOILED FUSION REACTION UNASSIGAND OR INDIVIDUAL, 7 ol 01 UNASSIGNED OR IKOIVIDUAL 7 0]. 05 U.S.A. ATOMIC ENEIXYY OOMM 4 ol 03 U.S.A. ATOMIC ENERGY COMM 4 ol 05 U.S.A. ATOMIC ENHRGY COMN 4 ol 05 TWW INC.

01 05

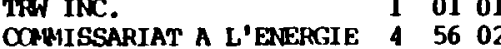
COLIMTRON OORPORATION 1 0] 02 U.S.A. ATOMIC ENERGY COMY 4 Ol 08

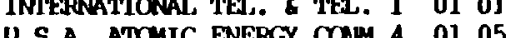
U.S.A. ATOMIC ENERCY COAM 4 0] 05 $\begin{array}{llll}\text { U.S.A. ATOMIC ENERGY OOMM } 4 & 01 & 12 \\ \text { U.S.A. ATOMIC ENFERY COMM } 4 & 01 & 01\end{array}$

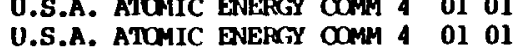

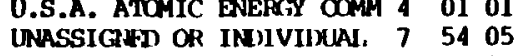
INTERANATIONAL TFI.. \& TEI. 1 ol 03

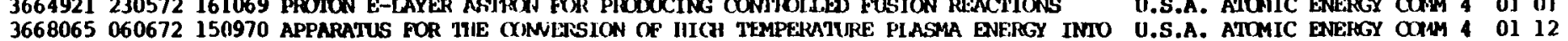

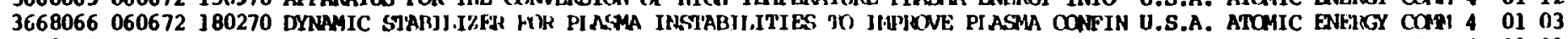
3668067060672161069 POIYGONAL ASTPON RENCTOR FOR PRODUCIIX; CONIROJJID FUSICN RENCTIONS U.S.A. ATOMIC ENEIYGY COMN 4 OI O1 3668068060672210169 PLASTA CONFINEMENT N'PNINIULS 3674634040772210169 PIASSA CONFIRIFHI:NI AYI'ARATUS

3677889180772060770 MMEETIC COMPRESSION COUJTCH JFD THFIUMNUCIFAR REACTOR UNITED KINCDOM ATOMIC ENE 4 B5 01 UNITED KINGTOM ATRMIC ENE 485 ol

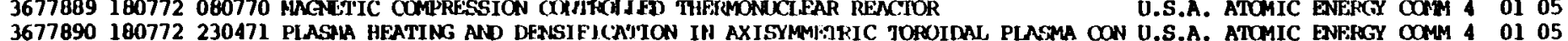

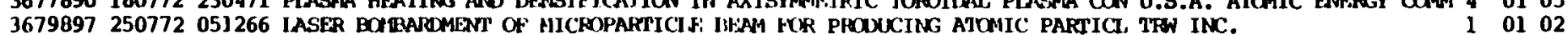
3692626190972210369 APRARATUS FOR FOIQ4IIK: MND CONTAINING PIAS71A

3702163071172150470 DEVICE FOR OOMPRESSION HFA'J]NG OF TOKAMAK DISCHARGES

U.S.A. ATOMIC ENERGY OOMM 4 Ol 01 3708391020173200971 DEVICE EOR OOAPRISSTON HFA'IJG OE TOKAMAK DISC

U.S.A. ATOMIC ENERTY COMH 4 ol 05

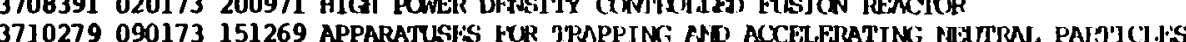

HETI, TELETMIHA: LABOPNTORI 1 0] 09

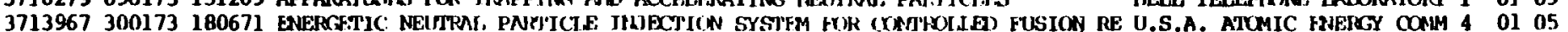


3715595060273110570 PULSED NEUTRON SOICE 3715625060273120171 PLASMA GENERATOR

3718836270273181170 MULITPACTOR ION GENEIRATOR 3719554060373110970 HALL CURREN' ACCETHIMATYR ND 3720828130373180870 APPAPATUS FOR AND MEIFION OF CONIFOLIING RET ATIVISTIIC CHARGFD PARTICL 3723246270373270571 PLASMA PROXUCTICN API'ARATISS HAVIN

3723703270373080271 IASER ENGRGIZED PIASAM SUUIRCE

3728217170473050672 BUPPY TORUS PIASHA CONFINF24INT DEVICE

3733248150573180270 PLASMA CONIROA BY FEHI)(SACK

3735591290573300871 MAGNETO-PLASIA-DYNAMIC ARC THRUSTER

3736539290573180472 MOMENT-FREE TOROIDA., MANANETI DESIG

3740554190673130472 MULTI-ANPERE DDOPICAIFON ION SOURCE

3742219260673230671 HIGH ENERGY NEUTRAI, PAPTICIF: BEAM SOURCE

3746860170773170272 SOFT X-RAY GENERATOR ASSISTFD BY IASER

3748226240773180572 PUISED HIGI-RFTA FUSJON RFACTOR

3748475240773170272 NEUIRON GENERATOR AXIAJJY ASSISTFD BY LASER

3749639310773110370 METHOD AND DEVICF: F(V PFODUCING THETAONMCJ EAR PIASTA

3750070310773301171 PRESSURE RING FOR JTANSSPOPHENR WINDINGS

3755073280873210671 MYREID LASER PLASAM T'ARGET-REUI'RAI, BEAM INUECTION EUSION SYSTEM

3755710280873240372 GAS PLASMA DEVICE

3757114040973080372 APPARATUS AND HEIHOT FOR MIASURING 71E INIENSI'TY OF A BEAM OF NEXTKA $37575] 8110973201071$ ION ENGIN

3760225180973060672 HIGH CUKRFN PI ASMA SOIRCE

3761721250973060772 MATIER WAVE INITRFEROMIETRIC APPARNTUS

3764466091073200170 PRODUCTION OF PLASIAS BY IONG WAVELENXIIII LASE:PS

3766004161073190771 LASER ASSIST'FD NEUTTON GENFRATOR

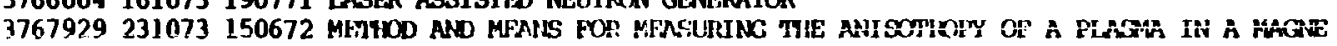

3769599301073220471 PAPTICIE PRFACCEISUIICH AFANG TIE

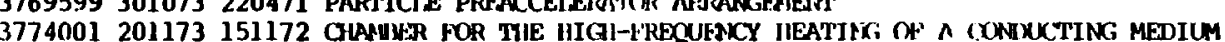

3778612113273151269 NEUTRAL PAPI'ICIE BFA SEPNAAIOR ANI VELOCITY ANALYZER USING RADIATIO

3778656111273260772 ION SOURCE DMPIOYIIK: A NJCTOWAVE RELWONANT CAVITY

3798488190374280771 PLASTM SOURCE OF CWNITH PARTICLES

3801438020474030470 TOROIDAL APPAPNIILS FO OWN ONFINING PIASMA

3808432300474151269 NEUTHAL, PAFI'JCLE ACCFITRRA'J(

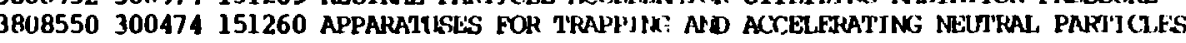

3815043040674110173 IASEA SYSTEM EMPIOYING RNIAN ANII-SIOKES SCATIERING

3816771110674090273 PLASMA ENERGY TO ELIXIRICAL, ENTSTSY OONVRRTET

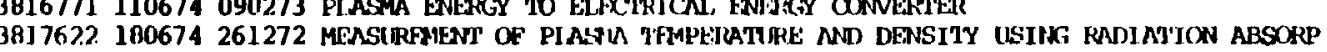

3831101200874050373 PARTICIE BFAM IHJFCIITN SYSTEM

3831121200874100773 FOCUSIIS MACNET

3843889221074291173 HICH INIENSIJY PROCIOH SOHFCE.

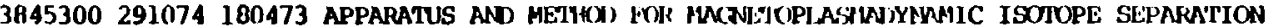
3846668051174220273 PIASTA GFNERATIIKG DHFVICE

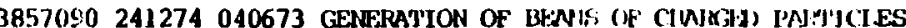

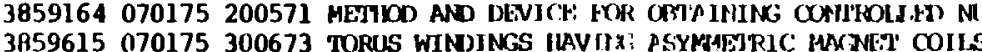

U.S.A. SEC. OF AIR FORCE: 4 O 05 INIERAATIOAAL TFI. * TET. 1 01 02 UNITED RINCOON ATOMIC ENE 48502 J.S.A. ATOMIC ENERGY OOMM 4 0102 U.S.A. ATOMIC ENERGY OOMM 4 ol 02 U.s. ATOMIC ENERGY OMn 4 ol 01 U.s. A.

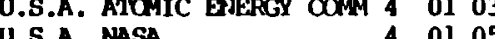
U.S.A. Masa 4 ol 05 U.S.A. MICMIC ENeiro cary 4 ol 06

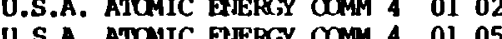
U.S.A. ATantC Ersor cam 4 ol 05 UNASSIENed dR INOTVIDInL 7 o1 14 U.S.A. ATCAIC ENERGY CONM 4 O1 05 UNASSIGND OR INDIVIDUnL 7 ol 05 UNASSIGNES OR INDIVIDUAL $7 \quad 68$ (12 WESTIINGHOUSE EIBCTRIC COR 1 01 06 U.S.A. ATOMIC ENERGY CON 4 O1 10 PARK-OHIO INDUSTRIFS INC. 1 01 02 BELI TELEPHOF \&. I ABORATORJ 1 0] 07 MESSERSCHMITT-BOIKOW ISLOI I 5405 U.S.A. ATCMIC ENERGY COMM 4 0102 TFW INC.

$\begin{array}{lll}1 & 01 & 07 \\ 4 & 01 & 05\end{array}$ U.S.A. ATONIC FNFRRY COMN 4 ol 05 U.S.A. SEC. OF THE NAVY 4 Ol 05 Iromson-CSF EN OMMISSARIAT A L'ENERGIE 4 56 05 Cara UNASSIGIED OR INDIVIDUAL 7 01 09

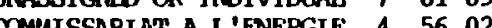
U.S.A. ATOAIIC ETHERGY OANM 4 ol 03 INASSIGANED OR INDIVIDUAN. 7 68 02 U.S.A. ATONIC ENERGY CONH 4 ol 01 BES.I. TH. FPFICNE LALORATCRI 1 0105 BEIL TET.EPIDNE LABORAJORI 1 01 05 U.S.A. ATOMIC ENERGY OOMM 40105 U.S.A. AICMIC ENERCY COMM 4 ol 12 U.S.A. NASA 4 ol 07 PIYSSJCS IMTERNATIOHAL: 00.10105 MAGA ITX STSTEMS, INC. 10106 U.S.A. SEC. OF AIR FORCE 4 01 02 U.S.A. ATCMIC ETNEPGY OOMH 4 ON 09 U.S.A. ATOMIIC ENERGY OON" 4 0102 NATIONAL RESSFARCII DEVEIOP 1 05 07 UNASIG H U.S.A. ATOMIC PAERGY COMM 40106 
PAGE NO. 00005

PATFINI ISSUED FILFD

TITIE

ASSICNFE:

SE CO 'IY

CT UN PE

OR TR

3866414180275180473 ION EXGINE

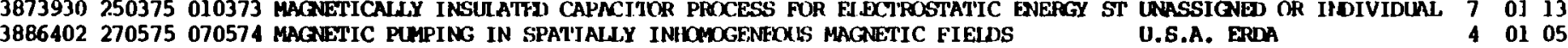

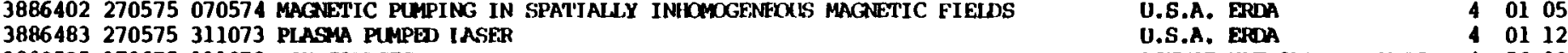

3890535170675111072 ION SOURCES

390009190875270674 ABSORPTION APPARATUS FOR NDJACFTMIY DISPOSED MAGNET COILS

3911318071075290372 METHOD AND APPAIATIS KOR GENERTING ELLCTTOMAGNIIIC RAIIATION

3914766211075291064 PULSATIMG PLASTA DENICE

391967711175 050774 SUPFORT STRUCIURE FOR A SUTEROONDUCTING MAGNET

3925990161275280873 SHOCK HEATED WAJ, OOHFINFJ FUSION POWER SYSTKY

3935503270176261173 PARTICIE AOCEI ERATOR

3935504270176160871 MEITIOD ANO APPARATUS FOH INJECTION OF' PIASMA

3937917100276220273 METIOD FOR PHODKICING AND HEATING A PLASMA

3946240230376040474 ENERBETIC ETLCTRON BEAM ASSISTED FUSION NFUTRON GENERATOR

3953731270476271273 ISOTOPE SEPARATION II'TIIZING ZEEIAN COMPENGATFD MAGAETIC EXIRACTION 3955153040576170375 RING LASER FOR PFNETRAT'ING WAVES

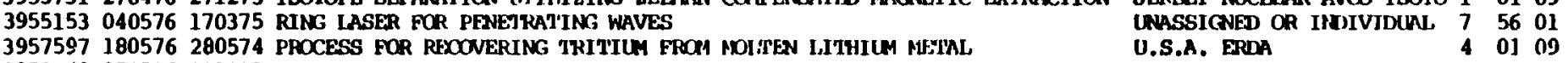

AGEACE NATIONAL DE VAIORI 45602

SIPMENS AKTIBNGESFIISCHAF 15406 FUSION SYSTEMS CORP. $\begin{array}{llll}\text { FUSION SYSTEMS CORP. } & 1 & 01 & 05 \\ \text { UNUSSIGNED OR INDIVIDUAL } & 7 & 01 & 05\end{array}$ WISC. AUW OR RES, FOMOAT 6 OI 00 WISC. ALUNI RFS. FOURDAT 6 01 06 U.S.A. SEC. OF AIR FORCE 4 01 05 RREIDI, CHIEMIOD PHYSICAL 1 65 01 COMUISSARIAT A L''ENERGIE 4 56 02 $\begin{array}{llll}\text { OOMPISSARIAT A L' ENERGIE } & 4 & 56 & 02 \\ \text { U.S.A. SEC. OF THE NAVY } & 4 & 01 & 05\end{array}$ 作

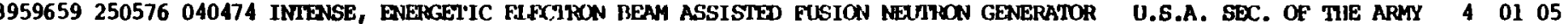
3959710 250576311274 METHOD FOR EXCIITMK IMXKCTIVE-RKSISTIVE LOADS WITH HIGH AND CONIROIL, U.S.A. ERAA 3969628 130776040474 INTENSE, ENERCFTIC EIFCIRON IIFAM ASSISIED X-RAY GENERATOR 3969631130776200375 GAS PROOUCTION APPAPNTUS

3973926100876230174 PROCESS AND EQIIPMHJII I.CR THE MAGNET'IC SEPARNI'ION OF ISOTOPES

3973926100876230174 PROCESS AND EOIIPMEPT FOR THE. MACNETIC SEPARATION OF ISOIOPES

3979694070976030774 SHORT LASER PUISE G NNFPA'JION BY CAS BREAKDOWN SWITUIING AND IIIGHI.Y

3980916140976220775 BENM LIMITER FOR THFINONUCLEAR FUSION DEVICE

3983695051076120975 ION BEAM THIRISTER SIIIFID

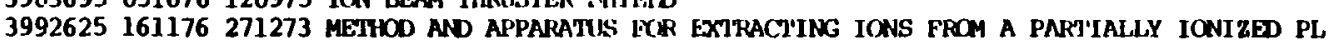

3995136301176180374 ENILAKCED LASET BEAM CUUPLIKG IO A PLASMA

3999072211276231075 BEAH PIASNA TYPE ION SOIICE

4000036281276280870 PIASTIA CONIFOI. ANII IIIIIIIYAT'ION

4007392080277160474 AMGNETIC WEIL FOR PIASNA CYNFINFMI:NI

4010396010377261173 DIRECT ACTING PLACMU ACCFIERMTOR

4023065100577241073 METHDD MD APPNAATUS FOR GLNEFATING AND UTILIZING A OCMPOUND PLASMA

4034260050777190276 GRIDDED CROSSED-FIFLD IIBE AND ICNIJ'ION MLITIDO

4035656120777270575 METHOD AND APPARATUS KYH LSE: IN APPFOACHING THEFHONICI EAR TEAPERATT 4042848160877170574 HYPOCYCDOIIN. PINCH DEVICE

4044562300877020574 MUTTIPOT'ARY ENFIKGY OONVEISSION VN.VE 4047068060977261173 SYMCHROROUS PIASMA PACKIFI ACCFLLEJAICR

4057462081177260275 RADIO FREQUENCY SULFT'AItIFI IOtI ENERGY

$405976] 221177270375$ SEPARATION OF ISCIOPES FY TIME; OF FLJCHT

4064024201277010676 AETIOOS FOR RADIATION PFODUCTION OF FUFIS

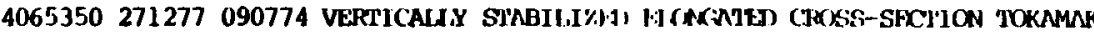

4065351271277250376 PAKTICIE REAM INUBCT'JON SYSTEM

4066496030178110974 CRYOCENIC EXPANSIJON JOINT FOR LNK

4066893030179270375 ISOIDPE SEPNRAT'ION RY ION WAVES

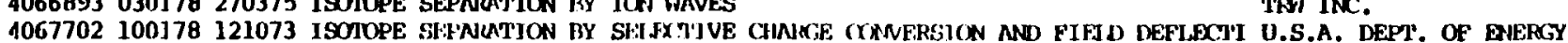

U.S.A. SEC OF THE ARMY 40105

U.S.A. EROA

ADVANCED TYCTINOLOCY LABOR 1 ol 09 ADVANCD TECHNOCGY IABOR 1 ol 09 BEJ I, TEI EPPENE LABORATORI 1 01 05 U.S.A. EROA 40104 U.S.A. NASA 40105 U.S.A. ERDA SHARP KABUSHIKI KAISHA 15505 U.S.A. EPRA 40105 IOWA ST. UNIV. RES. FONN 6 ol 01 KREIDL CIIMION PIIYSICAL 1 65 01 UIASSICNED OR INDIVIDLAL 70101 COMANY 1 ol 13 LADSSIGEDO OR INOIVIDUAL, 7 ol 02 UNSSIGNED OA IHOIVIDIAL, 7 al 12 KREIDL, CHF24ICD PIYSICAI, 19505 I.S.A. ERDA

$\begin{array}{lll}4 & 01 & 05 \\ 1 & 01 & 09\end{array}$

TFEAS GAS TRANSAISSION 001 l 01 U.S.A. DEPT OP ETERG a 40101 U.S.A. DaPD OP ERET 40101 
4068147100178061175 METHOD AND APPARATYLS HOR HEATING AND (OOPFISSSING PIASMA 4073680140278260675 TOROIDA. BAND LIMITER FOR A PIASHA CONTAINAENT DEVICE 4081677200378270375 ISOTOPE SFPARATION BY MAGNFI'IC FIFIDS

4086506250478050876 OONRA-POTATTNG HOHOPOIAII HOICRR-GIMNERATOR FOR ENERGY STORAGE AND RET 4087322020578070976 AIR OORE POIOILAL MARAF''IC: FIEID SYGTFM FOR PFODUCING A TOROIDA 4087720020578051076 MULTI-BEAM MULII-ALFERAIUIE: ION SOLRCES OF IFIF. BE'AM-PLASTA IYPE 4087721020578120576 ION SOUPCE USING A IKUJ CN CATHODF; DISCIIAPGE ARPANGFMENI' AND IN PARTI 4091256230578160175 PUISED ATCMIC BE'AM APPARATUS

4092534300578391176 CHAPGE EXCHANGE SYSTPH

4093856060678090676 METHOD AHD APPARATUS FUR THE EIECIPOSTATIC EXCITATTION OF IONS 4097348 270678. 070674 METHOD AND APPARATTLS FYIR PRODUCING IYYDROGFN

4090643040778090774 DURL-FUNCTION MAGIVIIC STRUCTURE FOR TOPOIDAL PLASMA DEVICES 4099053040778020577 DEVICS FOR THE SEPNFATION OF GAS MIXTURES

4101765180778190776 MEANS FOR OONNTERACT'ING CHARGED PAIT'ICLE BEAM DIVERGENCE

4110595290878190575 H1G1-FREXUENCY PLASIA-HFATTMG APPARATUS

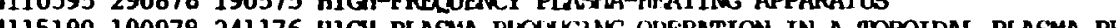

4115191190978140677 TOKAMAK PIASMA HEAT'TNG WITH INITNSE, PULSED, ION BEAMS

4116264260978051174 MUCIEAR RFACIORS

4121123171078170377 EXPIOSTVELY DRIVEN PIASTA CURRENI GBNERATOR

4121984241078091173 PRODUCTION OF HYIXYXit2N HY RADIOLYSIS

4123683311078150977 EIONCATE CROSSEDT-FIFIO SWITCH DEVICE

4125431141178160677 TANOEM MIIRKOR PIASM CONFINFTH DH APPNRATUS

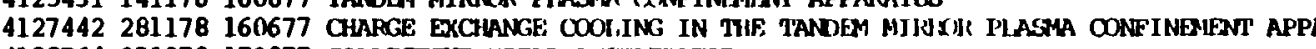

4128764051278170877 OOLACTIVE FIEID ACCFI.FINTOR

4) 29772121278121076 ELDCTRODE STRUCTIU:S FOR HIGI ENERGY HIG! TEMPERATURE PLASMANS

4130781191278140377 HIGH VOLTACE D-C VACLKM IRTERRRUPTER DEVICE WITH MAGETTIC CONTROL O

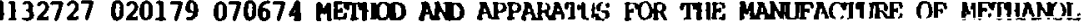

4137012300179071077 MODULAR GETTFR PUAPS

4140057200279020578 AXISTMMEIRIC STABILIZKN LINER IMIPIOSION SYSTEN

4140576200279220976 APPARATUS FOR THE NEUITALIIZATION OF ACCEIFISATT) IONS

4140577200279220976 PHOTODETACHMEMT PROCFSS FOR BEAM NEITRAL.IZATION

4140600200279191173 MUTI-STEP CHENICAL ND RADIATION PROCESS FOR IHE PRODUCTION OF GAS

4140601200279191173 MULTI-STEP CIEMICNL AAD RADIATION PROCESS

4140602200279020975 METHOD FOR OHTAINING CARION DIOXIDE FKOM THE ATMOSPIIFRE AND FOR PRO

1140603200279 . 19]173 MULTI-STEPCIENICNI. NA) RNDIATIOI PFCCFES FCH THE PRODUCI'ION OF CAS

4140603200279 . 19]173 MULTI-STEPCIDNICAI. NH) RNDIATIOI PR(CFESS FCH THIE PRODUCIION OF

4140943200279010677 PLASMA GFTERATIING DEVICE WITH ILAIRPIR SIIAPFD CATIODE FILAME

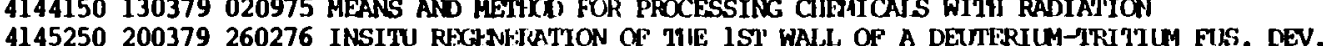

4145269200379191173 MUITI-STEP CHEMICA, ANI) ILDIATION PIOCESS FOR TIIS: PRODUCTION OF GAS 4145269200379191173 MUITII-STEP CHENICN, ANM INDIATION PIYXISS FOR TII:

4149077100479240877 MEIHOD FOR SEPNPNIION OF I.ITHIIN ISOTC

4149931170479160773 DIVEFIOR FOR USE IN FUSION REACIORS

4152625010579080578 PLASFA GENERATION ARD CONFIKISTS WITH OONTINUOUS WAVE LASERS

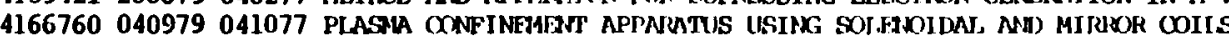

4)66761 040979070278 FUSION ClLANGBER

4167680110979060977 PROCESS AND APPARATIS IDR SFPN:AT'TNG JSOIOPES

4172008231079230877 NICIFAR FUSION REACIOR

4174254131179120977 OOMPRESSION HUB
UNASSIGNFJ OR INUJVIIXUAL $7 \quad 0105$ U.S.A. DEPT. OF ENERGY 4 ol 04 TrW INC.

$\begin{array}{lll}4 & 01 & 04 \\ 1 & 01 & 09\end{array}$

$4 \begin{array}{lll}1 & 01 & 13\end{array}$

$40] 06$ 15505 15602 . .A. DEPT. OF ENETGY THOMSON-CSF U.S.A. SEC. OF AIR FORCE 440105 .S.A. DEPT. OF' ENERGY 4 01 05 TEXAS CAS TRANOISSION $\infty \begin{array}{lll}1 & 0] & 09 \\ 1 & 01 & 10\end{array}$ U.

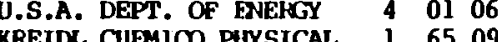
KREIDL, CIIEMIOO PFIYSICAL 116509 U.S.A. DEPT. OF ENLFGY 4 0105 U.S.A. DEPT. OF ENERGY 4 01 05 U.S.A. SEC. OF THE NAVY 4 0] 05 EUTCEEN ACMIC ENEKGY CO 4 9014 U.S.A. SBC. OF AIR FORCE 4 0105 TEXAS GAS TRANiTISSION CO 1 O1 10 HUGIES AIRCRAFT COMPANY 1 ol 13 U.S.A. DEPT. OF ENERGY 4 0101 U.S.A. DEPT. OF ENERGY 4 0103 U.S.A. DEPT. OF ENERGY 40105 WISC. ALUNI RES. FOUNIAT 6 ol 02. COULD INC. S.A.E.S. GETTERS S.P.A. I 6108 U.S.A. SEC. OF TTEE NAVY 4 0105 U.S.A. DEPT. OF ENEISY 40105 U.S.A. DEPT, OF ENERRG 4 ol 05 TEXAS Gas TRANSMISSION 001 l 0110 TExas Gas TRANCaISSION 001 ol 10 TEXas gas transaission co I 01 lo IEXAS GAS TRANSMISSION 0011 ol 10 .S.A. DEPT. OF FNERGY 40102 TEXAs gas TRANSMISSION 001 1 0110 Gevara M.I.T.I. M.I.T.I. 45509 I.S.A. DEPI'. OF ENERGY 4 Ol 04 U.S.A. SEC. OF TIE NRYY 4 ol 05 SERRSEY NUCI.EAR-AVCO ISOIO 1 01 09 U.S.A. DEPT. OF ENEICYY 4 Ol 01 URASSIGNJJ) OR INDIVIDUAL 7 ol 05 $\begin{array}{llll}\text { THOMSON-CSF } & 1 & 56 & 09 \\ \text { DUBRIE WIAMNY INC } & 1 & 01 & 01\end{array}$ COMBUSTION ENGINEFRING IN 1 ol 06 
PAGE NO. 00007

4179599181279080578 LASER PLASMATRON

4182561080180100671 PULSE DEUTERIUA LITIUU NUCIFAR RFACTOR

4182650080180170573 PUISTO NKCTEAR FUSION REACTOR

$41836 \% 1150180140378$ IMTEPRPEPOMETFE FOR THE MEASIRPMENT OF PIASHA DENSITY

4194139180380230878 REF1EX TEIROOF, FOR PRODUCING AN EFFICIEAT (NID) RFX'TIONAL ION DEAY 4199402220460230276 PIASTA ENERGY PRODUCTION

4199685220480140477 IASER BEAM ACTIVATFD ION SOLPCE

4202725130580 080578 OONERGING BEAM FUSION SYSTEM

U.S.A. BAC. OE IHE ARMY 4 O 05 UNASSIGNED OR INDIVIUUAL 75405 $\begin{array}{llll}\text { UNASSIGED OR INOIVIDINAL } & 7 & 01 & 05 \\ \text { U.S.A. DEPT. OF ENERGY } & 4 & 01 & 07\end{array}$ $\begin{array}{llll}\text { U.S.A. DEPT. OF ENERGY } & 4 & 01 & 07 \\ \text { U.S.A. SEC. OF THE NAVY } & 4 & 01 & 05\end{array}$ $\begin{array}{llll}\text { U.S.A. SEC. OF THE NAVY } & 4 & 01 & 05 \\ \text { UNASSIGNED OR IFDIVIDIAL } & 7 & 01 & 01\end{array}$ $\begin{array}{llll}\text { UNASSIGNED OR IFDIVIDIAL } 7 & 01 & 01 \\ \text { UNASSIGEST OR INDIVIDIAL } 7 & 71 & 09\end{array}$ UNASSIGESE OR INDIVIDTIA 7 OR INDIVIDIRL 7 ol 01 4209703240680011074 SOUKCE FOR PIASMA OF LNRGE TTAALSVERSE SECTION AND CONSTIIITPING AN IO UNASSIGNED OR IFUIVIDUAN 756 02 4209704210680140878 TANDEM ION ACCETERATION HIAVING MNITER-FREE ION CHARGR REVFINSW ZONE SIFMENS AKTIENGESEILLCTIAF 1 54 05

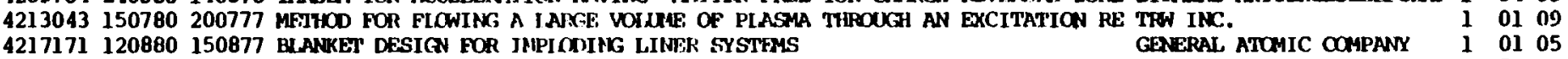

$42171721208 B 0131077$ COOLANT SYSTFM \& CXOLING METTIOD UTILIZING 2-PIASE FLOW IN REACTORS 4228380141080241078 METHID AND APPARATTS FOR HEATING AND COMPRESSING PLASI

4229679211080050674 PIASMA CONTPOL, SYSTEM

4229942 281080 060678 PADIOLYTIC DISSOCINTIVE GAS PONER CONVERSION CYCLES

4232244041180251078 COMPACT, MAINTAINABU.E O0-KFV NETTRAL BENA MOOULE

4233537111180180972 MUITICUSP PLASFIA CONTAINAENT APPARATUS

$\begin{array}{llll}\text { GENERAL ATOMIC COMPANY } & 1 & 01 & 05 \\ \text { TOKYO INSTITUTE OF TEXTIN. } & 2 & 55 & 12\end{array}$ $\begin{array}{llll}\text { TOKYO INSTITUIE OE TEXIN. } & 5512 \\ \text { TRISOPS INC. } & 1 & 01 & 05\end{array}$ UNASSIGTS OR IRDIVIDUA, 7 ol 03 KMS kUSION, IIXC. 190112 U.S.A. DEPT. OF ENERGY 4 o1 05 UNASSIGNED OR INDIVIDIAL 7 \% TOKYO SHIBAURA DENKI KK 15513 BRIGHAM YOUNG UNIVESSITY 2 01 01 BRIGHAM YOUN, UNIVERSITY 2 01 l 01 U.S.A. DEPT. OF ENERGY 4 0104 4235668251180251072 OONFINFNIENT OF HIGH TFMPFRATURE PLASMAS

4239594161280290875 CONROL OF IRIPURITIES IN TOROIDAL PIASMA DEVICES

4240873231280220978 COLAVIDAL FISION SYSTEH

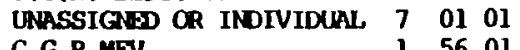

4243916060181170479 MACNETIC MIRPOR FOR BEAMS OF CHARGED PNHTICTES ACCFIERATED IN AN ACC C.G.R.MEV 4244782130181251077 MUCTER FISION SYGTEH

1246067200101300878 THERMONUCLEAR FUSION SYSTEM

4247804270181040679 COID CATHODE DISCHARTE DEVICE WITH GRID OONTROL

$\begin{array}{llll}\text { ENVIRONMENIAL INST. OF MI } & 3 & 01 & 01 \\ \text { UNRSSIGNED OR INDIVIDLAL } & 7 & 01 & 01\end{array}$ HUGSES AIRCRAFT CONPANY $1101 \quad 13$

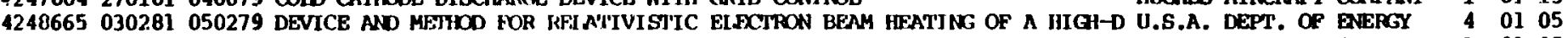
$\$ 252605240281$ 150877 SELF-IHPLODING I.INFR SYSTEM HOR MAGNIIIC FIFID OOMPRESSION 4252606240281060678 METHOD AND APPAPATUS FOA CONFINING A PIACMA

4252607240281050279 RADIATION SOUCE

4252608240281160379 GENERATING END PIIK, POTHYTIALS IN TNDEN MIRIOR PLASTA OONEINEMENI

4252609240281241178 CROSSED-FIEID DIVERTOR FOR A PIASNAA DEVICE

4263096210481020276 TOPOIDAL MNGWI' SYSTIP

4263097210481230277 METHOD AND APPARATUS FOR DFJVING A CORJ'INULOLS CURRENI IN A TOPOIDAL

4264413280481221276 METHOD AND APPANUTISS FOR IIITH BET'A DOUBI.ETS AND MUITIIPIETS

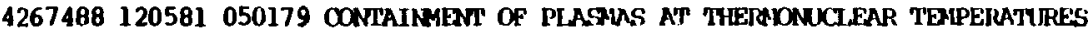

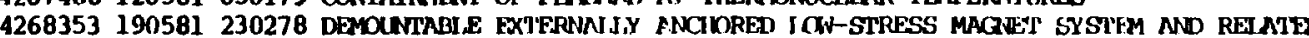
4269658260581020773 MECLIANICN, OOMPRESSSIITI HIASAM DEVICE

4269658260581020773 MECANANICAI, OOMPRES:IJON PIASTA DE.VICE

4269659260581230370 NEXTIRON GENERATOR

UNASSIGNED OR INDIVIDUAL 7 ol 01 U.S.A. DEPT. OF ENERGY 4 01 05 $\begin{array}{llll}\text { U.S.A. DEPT. OF ENERGY } & 4 & 01 & 01 \\ \text { U.S.A. DEPT. OF ENERGY } & 4 & 01 & 04\end{array}$ U.S.A. DEPT. OF ENERGY 4 0106 GENERAL ATOAIC OMMPANY 1 ol 05 GETERAL ATCMIC OOMPANY 1 01 01 TRISOPS INC.

4269659260581230370 NOTRON GENERATOR

U.S.A. DEPT. OF ENERGY 40106 GENERAL ATONIC CONPANY 1 ol 01 GENERRI. ATOMIC OOMPANY 1 o] 01 UNASSIGED OR INDIVIDUAL 7 OI 02 UNASSICNED OR INDIVIDUAL 7 ol 02

4272319090681 280278 DEVICE AND MET1MT FOR HTFCTYN BEN HEATING OF A IIICH DENSITY PIAST 4274919230681141177 SYSTEMS FOR MFIXINGG OF TDHOIDAI, PIACHAS

4277306070781221277 OOIL-LESS DIVIRTOIE FOR TOFOIINI, PIASRA SYSTIRIS

4277768070781241178 SUPEIXONDUCTINC MACNIFT IC COIL.

4282436040881 O406RO INIENSE ION IIEAM GENFJAT'ION WJTH AN INVERSE REFLLEX TEETTYOUE (IRT)

$42 B 7022010901020179$ OOAPRFESION ILT FOR A FUISION RFACTOR SYST'EM

U.S.A. DEPT. OF ENERGY 4 ol 05 GrNERAL ATOMIC OOMPANY 1 ol 01 GENERA, ATOMIC COMIPANY I 0104 GPNERAL DYNAMICS OORP. 1 01 06 0.S.A. SEC. OF ThIE NMVY 4 ol 05 COMUSTION ENGIREERING IN 1 0] 06 
,

. 
PNL -4932

UC-20

\section{DISTRIBUTION LIST}

No. of

Copies

OFFSITE

7

Colin D. West

Oak Ridge National Laboratory

P.0. Box X

Oak Ridge, TN 37830

5

Thomas J. Kuehn

Energy Research Advisory Board

Department of Energy

Forrestal Building, ER-6

Washington, D.C. 20585

27 DOE Technical Information Center

ONSITE

DOE Richland Operations Office

H. E. Ransom

21

Pacific Northwest Laboratory

R. S. Campbell

L. O. Levine

M. B. Triplett

A. L. Slavich

W. B. Ashton (10)

Publishing Coordination (2)

Technical Information (5) 
